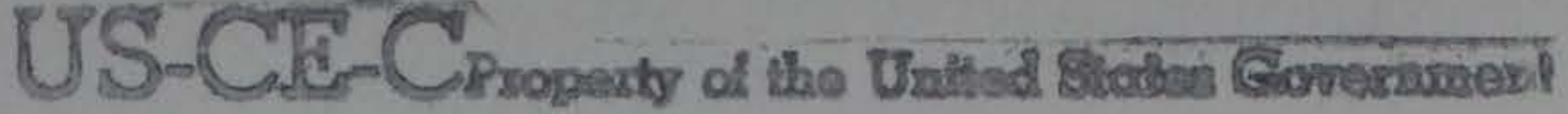

MISCELLANEOUS PAPER SL-83-16

\title{
ABRASION-EROSION EVALUATION OF CONCRETE MIXTURES FOR STILLING BASIN REPAIRS, KINZUA DAM, PENNSYLVANIA
}

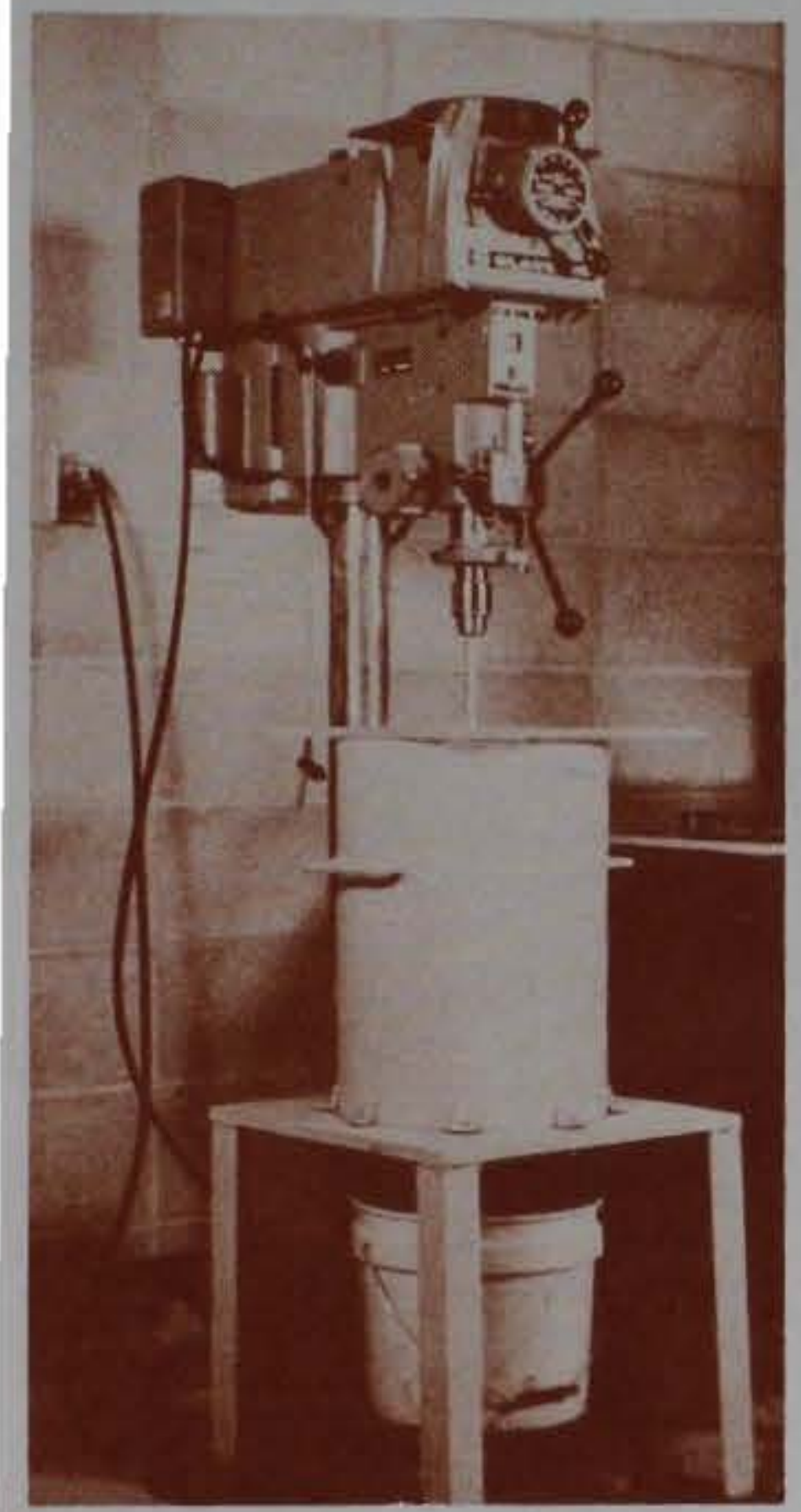

by

Terence C. Holland

Structures Laboratory

U. S. Army Engineer Waterways Experiment Station

P. O. Box 631, Vicksburg, Miss. 39180
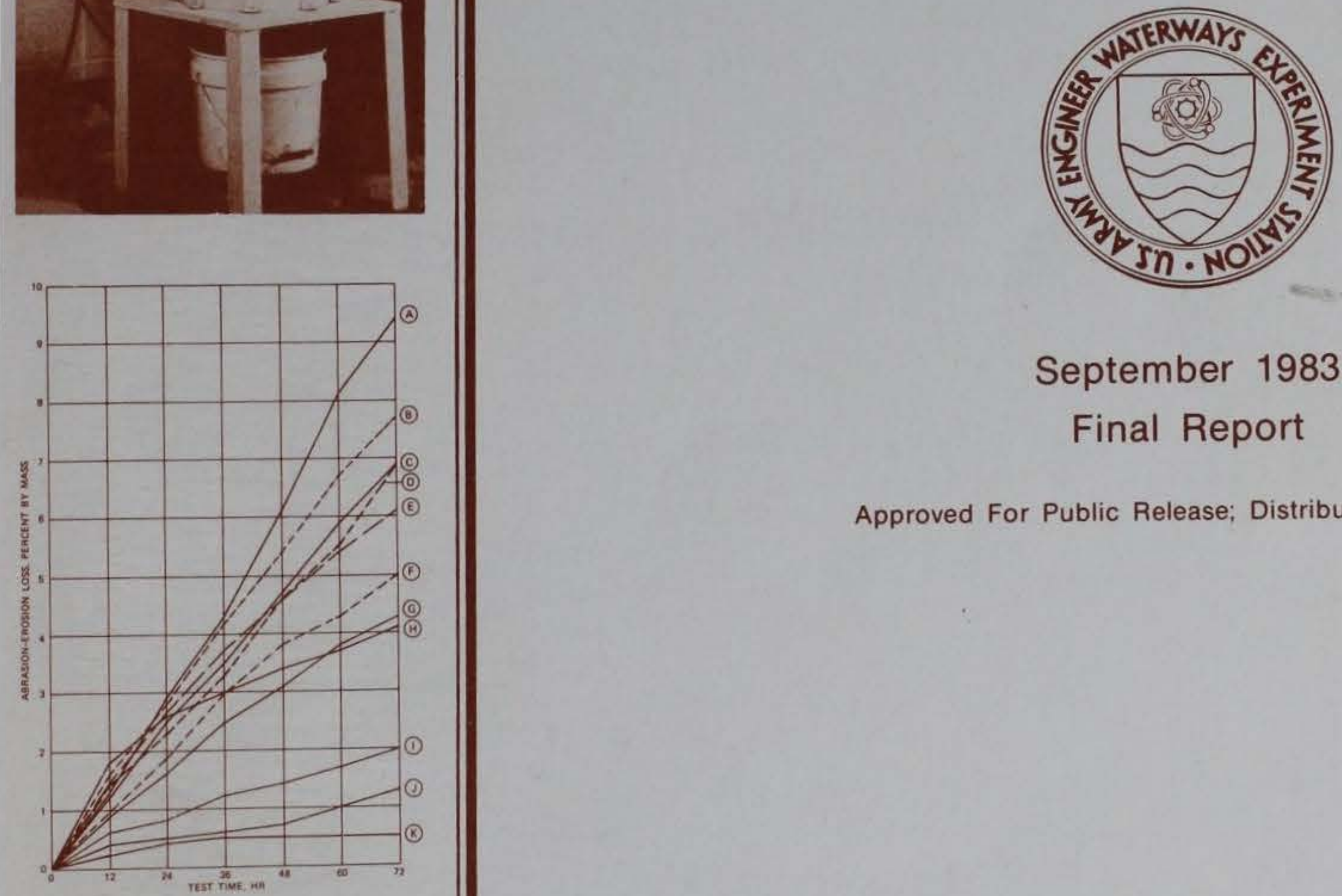

September 1983

Final Report

Approved For Public Release; Distribution Unlimited

LIBRARY BRANCH

TECHNICAL INFORMATION CENTER

US ARMY ENGINEER WATERWAYS EXPERIMENT STATION

VICKSBURG, MSSISSIPPI

U. S. Army Engineer District, Pittsburgh Pittsburgh, Pa. 15222 


\section{$9983083 \quad c .3$}

Unclassified SECURITY CLASSIFICATION OF THIS PAGE (When Data Entered)

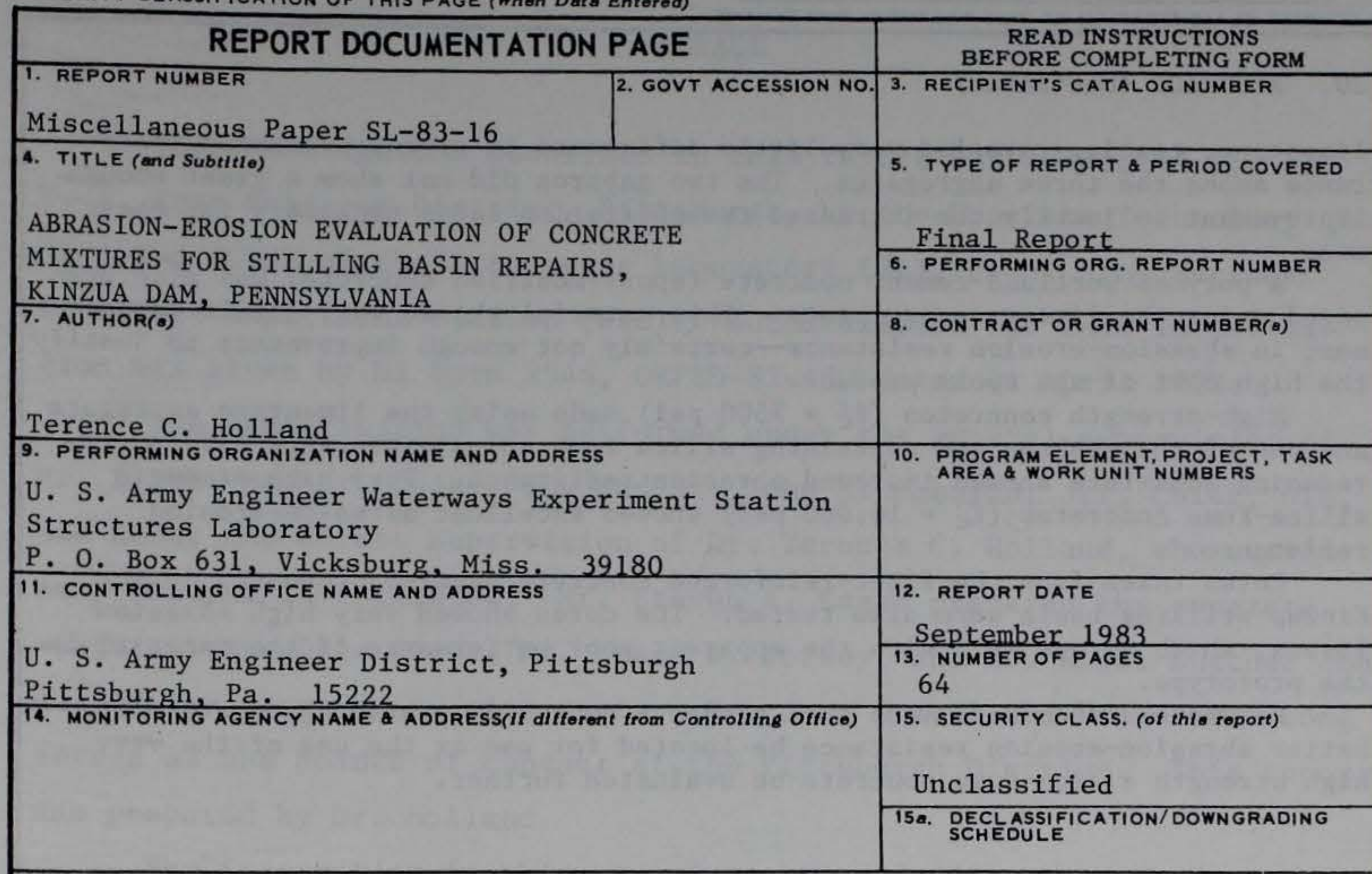

16. DISTRIBUTION STATEMENT (of this Roport)

Approved for public release; distribution unlimited.

17. DISTRIBUTION STATEMENT (of the abstract ontered in Block 20, if different from Report)

18. SUPPLEMENTARY NOTES

Available from National Technical Information Service, 5285 Port Royal Road, Springfield, Va. 22161.

This is CTIAC Report No. 67

19. KEY WORDS (Continue on reverse side if necessary and identify by block number)

Abrasion-erosion resistance (concrete)

Concrete properties

Kinzua Dam

Silica-fume concrete

20. ABSTRACT (Continue an reveras ofide if mecoseary and identify by block number)

The resistance to abrasion-erosion of several concretes made with

different coarse aggregates, with and without silica fume as a mineral admixture, was evaluated. Testing was done in accordance with the Corps of Engineers standard test method.

Initially, concretes made with a limestone coarse aggregate (available near the project site) and with two gabbros (from New York and Virginia) were prepared and tested. Although the gabbros were thought to be harder than the (Continued) 


\section{ABSTRACT (Continued)}

limestone, testing revealed very little difference in abrasion-erosion resistance among the three aggregates. The two gabbros did not show a great enough improvement to justify the increased transportation costs necessary for their use.

A polymer portland-cement concrete (epoxy-modified concrete) was also prepared using the limestone aggregate. This material showed very little improvement in abrasion-erosion resistance--certainly not enough improvement to justify the high cost of the epoxy product.

High-strength concretes ( $f_{c}^{\prime} \simeq 7500$ psi) made using the limestone aggregate and one of the gabbros and containing silica fume and a high-range waterreducing admixture showed improved abrasion resistance. Very high strength silica-fume concretes $\left(f_{c}^{\prime}=14,000\right.$ psi) showed excellent abrasion-erosion resistance.

Cores taken from the fiber-reinforced concrete overlay presently in the Kinzua stilling basin were also tested. The cores showed very high abrasion losses, which agrees well with the apparent poor performance of the material in the prototype.

Recommendations were made that either a source of coarse aggregate with better abrasion-erosion resistance be located for use or the use of the very high strength silica-fume concrete be evaluated further. 
The investigation described in this report was conducted for the U. S. Army Engineer District, Pittsburgh, by the Concrete Technology Division (CTD) of the Structures Laboratory (SL), U. S. Army Engineer Waterways Experiment Station (WES). Authorization for this investigation was given by DA Form 2544, ORPED-82-48, dated 21 Apri1 1982.

The investigation was performed under the general supervision of Mr. Bryant Mather, Chief, SL, and Mr. John M. Scanlon, Jr., Chief, CTD, and under the direct supervision of Dr. Terence C. Holland, who served as principal investigator. Mr. Steven A. Ragan prepared the concrete mixtures; Mr. Dale Glass, Mr. Frank W. Dorsey, and Mr. Roger Buttner conducted the abrasion-erosion tests. Mr. John Gribar and Mr. Stuart Long served as the points of contact at the Pittsburgh District. This report was prepared by Dr. Holland.

The information in this report was provided to the Pittsburgh District as an informal letter report (WESSC letter, "Transmittal of Letter Report," dated 10 November 1982).

Funds for publication of the report were provided from those made available for operation of the Concrete Technology Information Analysis Center (CTIAC). This is CTIAC Report No. 67.

Commander and Director of WES during this investigation and the preparation and publication of this report was COL Tilford C. Creel, CE. Technical Director was Mr. F. R. Brown. 
PREFACE . . . . . . . . . . . . . . . . . . . . . 1

CONVERSION FACTORS, NON-SI TO SI (METRIC) UNITS OF

MEASUREMENT ........................ . . . . . 3

PART I: INTRODUCTION ................... . . 4

Purpose . . . . . . . . . . . . . . . . . . . 4

Scope......................... . . . . 4

Authority . . . . . . . . . . . . . . . . . 5

PART II: TEST METHOD, MATERIALS, AND CONCRETE MIXTURES . . . . . 6

Test Method . . . . . . . . . . . . . . . . 6

Materials ....................... 6

Concrete Mixtures . . . . . . . . . . . . . . . . 9

PART III: TEST DATA AND DISCUSSION . . . . . . . . . . . 12

Test Data . . . . . . . . . . . . . . . 12

Discussion ...................... . . . . 12

PART IV: CONCLUSIONS AND RECOMMENDATIONS . . . . . . . . . . 17

Conclusions . . . . . . . . . . . . . . . . 17

Recommendations ................... 18

REFERENCES . . . . . . . . . . . . . . . . . . 20

TABLES $1-25$

FIGURES 1-14

APPENDIX A: PETROGRAPHIC REPORT ON AGGREGATES USED . . . . . . . Al

APPENDIX B: EPOXY DATA SHEET . . . . . . . . . . . . B B

APPENDIX C: EPOXY MANUFACTURERS CONTACTED ........... C1 


\section{CONVERSION FACTORS, NON-SI TO SI (METRIC) UNITS OF MEASUREMENT}

Non-SI units of measurement used in this report can be converted to SI (metric) units as follows:

Multiply
cubic feet
feet
fluid ounces per
cubic yard
fluid ounces per
pounds (mass)
inches
pounds (force) per
square inch
pounds (mass)
pounds (mass) per
cubic foot
pounds (mass) per
cubic yard

\begin{tabular}{|c|c|}
\hline By & To Obtain \\
\hline 0.02831685 & cubic metres \\
\hline 0.3048 & metres \\
\hline 38.6738 & $\begin{array}{l}\text { millilitres per } \\
\text { cubic metre }\end{array}$ \\
\hline 65.1896 & $\begin{array}{l}\text { millilitres per } \\
\text { kilogram }\end{array}$ \\
\hline 25.4 & millimetres \\
\hline 0.006894757 & megapascals \\
\hline 0.45359237 & kilograms \\
\hline 16.01846 & $\begin{array}{l}\text { kilograms per } \\
\text { cubic metre }\end{array}$ \\
\hline 0.5932764 & $\begin{array}{l}\text { kilograms per } \\
\text { cubic metre }\end{array}$ \\
\hline
\end{tabular}




\section{ABRASION-EROSION EVALUATION OF CONCRETE MIXTURES \\ FOR STILLING BASIN REPAIRS, KINZUA DAM, PENNSYLVANIA}

\section{PART I: INTRODUCTION}

\section{Purpose}

1. The purpose of this investigation was to evaluate several concrete mixtures on the basis of resistance to abrasion-erosion damage. The data developed are to be used to assist personnel of the Pittsburgh District in selecting the concrete mixture to be used during the planned repair project. Of particular interest in the investigation was a comparison of a limestone aggregate available near the project site with two traprock aggregates which would have to be imported from either New York or Virginia. Additionally, members of the District staff had expressed interest in the evaluation of a polymer portland-cement concrete (epoxy-modified concrete).

\section{$\underline{\text { Scope }}$}

2. This investigation included testing six concrete mixtures cast using the various aggregates supplied by members of the District staff. Abrasion-erosion testing was also conducted on core samples taken from a large chunk sample of fiber-reinforced concrete removed from the Kinzua stilling basin. The investigation consisted of a petrographic examination of the aggregates, appropriate testing of the aggregates to determine properties necessary for concrete mixture proportioning; mixture proportioning and specimen casting; and abrasion-erosion and compressive strength testing. Because of the potential for application to the Kinzua repair work, the results of some related ongoing work sponsored by Headquarters, U. S. Army Corps of Engineers (HQUSACE), were reviewed and incorporated into this report. 


\section{Authority}

3. The work described by this report was authorized by DA Form 2544, ORPED-82-48, dated 21 April 1982, from the Pittsburgh District. 
PART II: TEST METHOD, MATERIALS, AND CONCRETE MIXTURES

\section{Test Method}

4. Abrasion-erosion testing was conducted in accordance with CRD-C 63-80,* "Test Method for Abrasion-Erosion Resistance of Concrete (Underwater Method)." This test procedure involves subjecting the concrete specimens to abrasion-erosion caused by the wear of steel grinding balls on the concrete surface. The steel grinding balls are propelled by water in the test chamber. The water is in turn propelled by a submerged mixer paddle. Test specimens are periodically removed from the apparatus to determine the amount of abrasion-erosion damage. The damage is quantified and reported as a percentage of original mass lost.

5. The development of the test procedure and data from a large variety of tests of various concrete mixtures was described by Liu (1980).

\section{Materials}

6. Materials involved in this investigation were the three coarse aggregates and one fine aggregate supplied by the Pittsburgh District. Other materials were laboratory stock. All materials used are described in the following paragraphs.

\section{Fine aggregate}

7. The fine aggregate, Structures Laboratory (SL) serial No. PITT-8 S-1, was from the Buffalo Slag Co., Franklinville, New York. This fine aggregate is classified as a glacial sand and is composed primarily of limestone and sandstone fragments. There was some clay present in the sample, but it was determined not to be a detrimental swelling clay. Test results for this aggregate (grading, specific gravity, and absorption) are given in Table 1 . The results of a petrographic examination are presented in Appendix A.

* A11 CRD-C test methods are published in the Handbook for Concrete and Cement (U. S. Army Engineer Waterways Experiment Station (WES) 1949). 
8. This fine aggregate meets the grading requirements of ASTM C 33 , "Standard Specification for Concrete Aggregates" (CRD-C 133-81a), as well as both alternates for concrete sand of the guide specification for concrete (Office of the Chief of Engineers 1978).

9. Review of TM 6-370 "Test Data - Concrete Aggregates in the Continental United States," (U. S. Army Engineer Waterways Experiment Station 1953), showed that this fine aggregate (No. 42-78-3) was last tested in 1973. The material properties of the aggregate have not changed significantly since that time.

\section{Coarse aggregates}

10. The first coarse aggregate, SL serial No. PITT-8 G-1, was a limestone from the Neidigh Brothers Quarry, Boalsburg, Pennsylvania. The petrographic examination (Appendix A) classified this aggregate as a dolomitic limestone that is potentially reactive when used with a highalkali cement. Materials test data for this aggregate are presented in Table 2 .

a. This coarse aggregate does not meet the grading specification of ASTM C 33 (CRD-C 133) for a $1-1 / 2$ in.* to No. 4 (size No. 467). The material does meet the specification for 1 in. to No. 4 (size No. 57).

b. Review of TM 6-370 showed that this coarse aggregate (No. 40-77-5) was last tested in 1962. The material properties have not changed significantly since that time.

11. The second coarse aggregate, SL serial No. PITT-8 G-2, was a diabase from the New York Traprock Co., West Nyack, New York. The petrographic examination (Appendix A) classified this aggregate as a gabbro. Materials test data for this aggregate are presented in Table 2 .

a. This coarse aggregate did not meet the ASTM C 33 (CRD-C 133) specifications for either size No. 467 or size No. 57 . The aggregate was crushed several times using a laboratory crusher to develop the "as processed" grading shown in Table 2. This aggregate, as received, was extremely dirty and had to be washed after final crushing and prior to use. The aggregate, as used, did meet the requirements for size No. 57 .

* A table of factors for converting non-SI units of measurement to SI (metric) units is presented on page 3 . 
b. Review of TM 6-370 showed that this crushed aggregate (No. 41-74-2) was last tested in 1966. The material properties have not changed significantly since that time.

12. The third coarse aggregate, SL serial No. PITT-8 G-3, was a diabase from the Luck Quarry, Leesburg, Virginia. The petrographic examination (Appendix A) also classified this aggregate as a gabbro. Materials test data for this aggregate are presented in Table 2 .

a. This coarse aggregate did not meet the ASTM C 33 (CRD-C 133) specification requirements for a size No. 467 . It did meet the requirements for size No. 57 .

b. Review of TM 6-370 showed that this coarse aggregate had not been previously evaluated for use by the Corps of Engineers.

Cement

13. The cement used, SL serial No. RC-888, was purchased from the Marquette Cement Co., Brandon, Mississippi. The cement meets the requirements of ASTM C 150 (CRD-C 201) for a Type I cement. The physical and chemical test results for the cement are presented in Table 3 . Admixtures

14. The silica fume used, SL serial No. AD-536(4), was from the Reynolds Metals Company, Richmond, Virginia. Test data for this material are presented in Table 4.

15. The air-entraining admixture used was Hunts Air-In, from laboratory stock. It is a neutralized vinsol resin produced by Hunts Process Corporation - Southern, Ridgeland, Mississippi.

16. The water-reducing admixture used was Hunts HPS-R, from laboratory stock. It is a lignosulphonate produced by Hunts Process Corporation - Southern, Ridgeland, Mississippi.

17. The high-range water-reducing admixture was Dowell D-65, from laboratory stock. It is a sulphonated napthalene formaldehyde condensate produced by Dowell, Tulsa, Oklahoma.

18. The antifoaming admixture was Dowel1 D-47, a laboratory stock item produced by Dowe11, Tulsa, Oklahoma.

19. The two-component liquid epoxy resin system, Sikadur 362, was produced by the Sika Corporation, Lyndhurst, New Jersey. It is described 
by the manufacturer as an epoxy modifier for concrete and mortar. The manufacturer's data sheet for this product is presented as Appendix B. Concrete sample

20. A large chunk sample ( 3 by 3 by $1 \mathrm{ft}$ ) of fiber-reinforced concrete which had been removed from the Kinzua stilling basin was shipped to WES for examination. Three 11-3/4-in.-diameter cores were removed from this sample. The cores were sawed perpendicularly to the direction of coring to provide specimens suitable for use in the abrasion-erosion test. Figure 1 shows the surface of the chunk sample after the cores were drilled. Figure 2 shows one of the original surfaces of the sample which was sawed from one of the cores.

21. The overall appearance of the surface of the concrete sample indicated it had been subjected to abrasion-erosion wear. Examination of the cut surfaces (cut either by coring or sawing) showed a reasonably good distribution of fibers. There were several areas in which small fiber balls were observed.

22. Attempts were made to take smaller diameter cores ( 3 in.) for compressive strength testing. Because of seams in the material, no usable cores were obtained.

23. The specimens obtained from the chunk sample were stored in a water tank for a minimum of 28 days prior to beginning the actual abrasion-erosion testing.

\section{Concrete Mixtures}

24. Six concrete mixtures were proportioned specifically to be tested for this investigation. These mixtures were based upon a reference mixture used in previous abrasion-erosion testing. A brief description of these six mixtures, along with the table in which detailed mixture proportions may be found, follows:

a. Mixture Kinzua G1 (Table 5): Pennsylvania limestone coarse aggregate.

b. Mixture Kinzua G2 (Table 6): New York gabbro coarse aggregate. 
c. Mixture Kinzua G3 (Table 7): Virginia gabbro coarse aggregate.

d. Mixture Kinzua G1(SF) (Table 8): Mixture Kinzua Gl with a 15 percent (by weight) replacement of cement by silica fume.

e. Mixture Kinzua G3(SF) (Table 9): Mixture Kinzua G3 with a 15 percent (by weight) replacement of cement by silica fume.

f. Mixture Kinzua G1(Epoxy) (Table 10): Mixture Kinzua G1 modified to include an epoxy at an epoxy to cement ratio (by weight) of approximately 0.20 .

25. Earlier abrasion-erosion work done by Liu (1980) showed that polymer portland-cement concrete (PPCC) (epoxy-modified concrete) was a good performer, even when used with a relatively soft aggregate. Based on Liu's results and the interest generated in the District by an item in Engineering News-Record (see para 42), Mixture G1 (Epoxy) was developed.

26. Mixture Gl(Epoxy) was proportioned using the same parameters used by Liu: a water to cement ratio (by weight) of 0.30 and a polymer to cement ratio (by weight) of 0.20 . The cement content of the concrete was increased slightly over that of the other Kinzua mixtures (534.4 to $564 \mathrm{lb} / \mathrm{yd}^{3}$ ) to bring it up to an even number of bags ( $94 \mathrm{lb}$ each). This was done to allow a whole number of epoxy units to be used in the mixture (most manufacturers specify a dosage rate of $x$ units per bag of cement). The epoxy selected, Sikadur 362, was available in the laboratory and was similar to that used by Liu. At the recommended dosage rate of $2 \mathrm{gal} / \mathrm{bag}$ of cement, the calculated polymer to cement ratio was 0.19 . It was also felt that if a PPCC were selected to be used in the field, dosage using a whole number of units of epoxy per cubic yard of concrete would be much easier to control.

27. The concrete manufactured with a water to cement ratio of 0.30 showed no cohesion and was unsuitable for use. Additional water was added to obtain a workable concrete. The addition of this water changed the yield of the batch and reduced the cement content per cubic yard below that of an even six bags. In the interest of economy, additional trial batches were not made. Such batches would be required to 
develop the final mixture proportions if the PPCC were to be selected for project use. The as-manufactured mixture proportions are presented in Table 10A.

28. The silica-fume mixtures using the Kinzua investigation aggregates were developed because of the high resistance to abrasion-erosion seen in the proprietary and nonproprietary silica-fume concretes tested under the HQUSACE-funded abrasion-erosion study. The two mixtures (GI(SF) and $G 3(S F)$ ) were first attempts that were intended to show whether addition of silica fume would be beneficial. These mixtures were developed by replacing 15 percent (by weight) of the cement with silica fume. The same water-reducing admixture was used in the silica-fume concretes as was used in the other Kinzua mixtures. The water-cement ratio was increased to obtain a workable concrete with a slump of approximately 2 in. These mixtures were not intended to be viewed as recommended proportions for repair since they were simply experimental in nature.

29. In addition to the mixtures proportioned using the Kinzua investigation aggregates, several other mixtures are cited in the data and discussion part of this report. These mixtures and the table in which exact proportions may be found (if available) are:

a. Chert reference concrete (Table 11): This is the current standard which is used for comparison purposes for abrasion-erosion testing.

b. Densit concrete. This is a proprietary concrete product containing silica fume, high-range water-reducing admixtures, and calcined bauxite aggregates. The samples were prepared by the manufacturer and no mixture details are available.

c. Mixture SF1 (Table 12): This is a nonproprietary silicafume concrete containing natural silica sand and 3/4-in. crushed granite coarse aggregate.

d. Mixture SF2 (Table 13): This is a nonproprietary silicafume concrete containing manufactured granite sand and 1/2-in. crushed granite coarse aggregate.

30. Because it is not considered essential for this report, data on all of the materials used in the mixtures not containing Kinzua aggregates have not been included. 


\section{Test Data}

31. The materials properties for the fresh and hardened concretes are presented in Table 14. Data presented for each concrete include water:cementitious materials ratio, slump, air content, compressive strength, modulus of elasticity, and Poisson's ratio.

32. Abrasion-erosion test data and photographs of the specimens after testing are presented as follows:

\begin{tabular}{llll}
\multicolumn{1}{c}{ Mixture } & $\begin{array}{c}\text { Abrasion-Erosion } \\
\text { Test Data }\end{array}$ & & Photograph \\
\cline { 2 - 2 } Kinzua G1 & Table 15 & Figure 3 \\
Kinzua G2 & Table 16 & Figure 4 \\
Kinzua G3 & Table 17 & Figure 5 \\
Kinzua G1(SF) & Table 18 & Figure 6 \\
Kinzua G3(SF) & Table 19 & Figure 7 \\
Kinzua G1(Epoxy) & Table 20 & Figure 8 \\
Kinzua Cores & Table 21 & Figure 9 \\
Chert Reference & Table 22 & Figure 10 \\
Densit & Table 23 & Figure 11 \\
Silica Fume 1 & Table 24 & Figure 12 \\
Silica Fume 2 & Table 25 & Figure 13
\end{tabular}

33. The abrasion-erosion test data are plotted in Figure 14.

\section{Discussion}

\section{Abrasion-erosion test results}

340. The initial review of the performance of the three basic mixtures, Kinzua G1, G2, G3, raised a question, particularly in view of the results presented by Liu. That question concerns the performance of the two traprocks (diabases/gabbros) in comparison to the limestone. Based 
upon Liu's results, the traprock samples would have been expected to perform significantly better than the limestone sample. Based upon the information plotted in Figure 14, it can be seen that there was very little difference in the performance of the concretes containing these three aggregates.

35. The answer to this apparent anomaly lies in the difficulty of attempting to prejudge the performance of a particular aggregate based upon a rock name. The resistance of an aggregate to abrasion-erosion damage is apparently closely related to the hardness of the aggregate. However, it is impossible to assign a correct value for hardness based upon a name such as traprock or limestone. Aggregates described using either term may exhibit a range of values for hardness (or any other property) based upon chemical composition, grain size, and degree of weathering.

36. The three Kinzua investigation aggregates, along with the WES laboratory stock limestone (used by Liu), the chert used in the reference mixture, and the Iron Mountain traprock used by Liu, were tested to determine relative hardness. Testing was accomplished by sawing a representative aggregate particle, polishing the surface, and scratching with a steel needle. The rankings, from hardest to softest, were: Iron Mountain traprock, chert, Kinzua G3, Kinzua G2, laboratory stock limestone, and Kinzua G1. The differences among the last four aggregates were not very great nor was the difference between the top two aggregates very great. There was, however, a significant increase in hardness between the bottom four and the top two.

37. Based upon the relative hardness of the aggregates, the performance of the three primary concretes appears reasonable. The slightly higher loss for Mixture G2 over Mixture G1, even though aggregate G2 tested harder than $\mathrm{Gl}$, may be attributable to the very large grain size of the G2 aggregate.

38. To comment further on the performance of Mixture G1, consider the following data taken from Liu's report for concrete containing the laboratory stock limestone aggregate: 


$\begin{array}{ccc}\text { Mixture } & \frac{f_{c}^{\prime}, \text { psi }}{3470} & \text { Loss, \% } \\ \text { T1 } & 6870 & 9.1 \\ \text { T2 } & & 6.1\end{array}$

If a straight-line interpolation is made using the compressive strength of the Kinzua G1 concrete, 5710 psi, a loss of 7.1 percent is predicted. This prediction agrees very well with the measured value of 6.9 percent. Since the relative hardness of the aggregates is very similar, the test results appear to be reasonable.

39. The two concretes containing the Kinzua investigation aggregates and silica fume, Mixtures G1(SF) and G3(SF), show losses of only 72 and 70 percent, respectively, as great as the same mixtures without the silica fume. When compared to the concretes intentionally proportioned for high strength, Mixtures SF1, SF2, and Densit, the performance of the mixtures containing the Kinzua investigation aggregates and silica fume appears to be reasonable.

40. The performance of Mixture Gl(Epoxy) is somewhat surprising. This concrete (Table 10A) is very similar to Mixture Gl (Table 5) with the exception of the addition of the epoxy. The compressive strength of Mixture Gl(Epoxy) was approximately 1340 psi less than that of Mixture Gl. The abrasion loss was much less than would have been expected for a concrete with a compressive strength 4370 psi, but the loss was higher than anticipated based on Liu's work with a similar mixture. Apparently, the epoxy coated the coarse aggregate particles and increased their resistance to abrasion, but it did not add to the compressive strength of the concrete. Why this occurred is not clear. This finding is not in keeping with the results reported by Liu or by Nawy and Sauer (para 42).

41. The performance of the specimens made from the fiberreinforced concrete taken from the stilling basin was in keeping with other data on the abrasion-erosion resistance of fiber-reinforced concrete reported by Liu and with additional testing accomplished since publication of Liu's report. 


\section{Polymer portland-cement concrete}

42. Essentially from the beginning of this test program, the District representatives had expressed an interest in the possible use of a PPCC as the repair material. This interest was apparently based, in part, on a news item that appeared in the Engineering News-Record (ENR) (1980). This short article described work done on PPCC at Rutgers University by Professors Edward G. Nawy and John A. Sauer. The article mentioned the properties of the PPCC, and it also stated that, "The product costs about $\$ 12$ to $\$ 15$ more per cu yd than standard concrete."

43. Liu had tested a PPCC in the first phase of abrasion-erosion testing. The material had performed very well. Based upon that performance and the low cost figure cited in the ENR article, the District requested that a similar material be included in the test program.

44. Professors Nawy and Sauer were contacted in regard to the ENR article. They furnished two reports (Nawy et al. 1978 and Sauer et al. 1975) describing their work. During discussions, both stated that they did not furnish the cost figures to ENR. In fact, they had received their epoxy products at no cost from the manufacturer.

45. To develop a basis for comparison, 11 epoxy manufacturers were contacted to determine which ones manufactured a product suitable for use in PPCC (Appendix C). Of the 11, 4 had such a product. The approximate list price for the epoxy needed for a 6-bag concrete mixture at the manufacturer's recommended dosage rate (all were close to a polymer to cement ratio of 0.20 ) ranged from $\$ 342$ to $\$ 639$. While some savings could be anticipated on a large volume purchase, the cost per cubic yard of concrete would still be very high.

46. In addition to the high cost of the epoxy product itself, there are other factors which could be expected to affect the cost of the concrete. These would include the short pot life of the epoxy and concrete, the more complicated batching sequence, the possible health hazards to the work crews, and any premium which a contractor might charge. 


\section{Edge treatment}

47. The proposed plan of repair for Kinzua calls for removal of fiber-reinforced concrete and replacement with a more abrasion-erosion resistant material only in the slabs most severely damaged. There are no plans at the current time to replace the slabs adjacent to the training walls on either side of the stilling basin. The slabs which will not be removed may show some loss of concrete, particularly adjacent to the slabs which will be removed. To preclude having a discontinuity in the surface of the stilling basin, the District plans to use a filler material which can be placed at the surface elevation of the replacement concrete and then feathered out to meet the surface of the slabs not removed. The District specifically requested assistance in selecting an epoxy mortar or similar product to be used in those areas.

48. The Corps has used a variety of epoxy mortars in stilling basin repairs (McDonald 1980). In general, these mortars have not performed well. A better approach than using an epoxy mortar would be to use the same material selected for the replacement sections for the tapered sections. Rather than attempting to feather the material, those slabs not being removed totally should have enough fiber-reinforced concrete removed to allow replacement with the main repair material to a minimum depth of 4 to 6 in.

\section{Reinforcing mat}

49. During a review meeting held on 22 September 1982, the question of using a reinforcing mat in the replacement material was discussed. The District would like to avoid use of a mat since the reinforcing steel could serve as an additional abrasion-erosion causing agent if future damage were to expose and free the steel. Portions of dowels used to anchor the fiber-reinforced concrete have been found in the stilling basin. The appearance of these dowels indicates that they may have been causing damage to the concrete in place.

50. From an abrasion resistance point of view, the presence or absence of a reinforcing mat is not a significant factor. There may be advantages to having a mat to help anchor the replacement overlay. However, adequate anchorage can also be achieved through the use of sufficient dowels. 


\section{PART IV: CONCLUSIONS AND RECOMMENDATIONS}

\section{Conclusions}

51. The poor performance of the fiber-reinforced concrete in the Kinzua stilling basin has also been seen in the abrasion-erosion test. The good correlation between the results from the field and the results obtained in the laboratory helps to establish the credibility of the test procedure.

52. There does not appear to be a significant difference between the abrasion-erosion resistance of the limestone and the two traprocks. There appears to be no advantage to importing either of the two traprocks to the project site for use in the replacement concrete.

53. The abrasion-erosion resistance of the concretes proportioned for high strength using silica fume and a high-range water-reducing admixture was excellent. These concretes performed similarly to polymer concretes (PC), polymer-impregnated concretes (PIC), and polymer portlandcement concretes (PPCC). The silica-fume concretes are significantly easier to manufacture than PC, PIC, or PPCC, and they should be significantly less expensive to produce and place. Addition of silica fume to the two mixtures containing the Kinzua investigation aggregates improved the abrasion-erosion resistance of the concretes. It appears possible, through the use of silica fume and appropriate admixtures, to develop a concrete using the locally available limestone aggregate (G1) which will have a resistance to abrasion-erosion at least as good as that of the chert reference concrete.

54. The use of a silica-fume concrete will require careful control and inspection. The batch plant will have to be capable of handling the silica fume in whatever form it is made available by the producer (slurry or dry). To achieve the full potential benefits of the silica fume, it will be necessary also to use a high-range water-reducing admixture (HRWRA). The use of a HRWRA will raise the problems normally associated with these products, particularly slump loss versus travel time from the batch plant. Overall, it must be recognized that a silica-fume concrete 
is a sophisticated material that will require greater than normal care and inspection. Unless the District is willing to commit the necessary resources to insure that the concrete is properly manufactured and placed, it would be better to select a more conventional concrete for the repair material.

55. Anchorage design should be based upon anticipated uplift forces which would be expected on the stilling basin overlay. Dowels should be sized and spaced based upon loss of all bond between the replacement and underlying materials. Since a relatively thin overlay is anticipated (12 in.), the dowels will probably need to be hooked to achieve the full development length of ACI 318 (American Concrete Institute 1977).

56. Because of the unexpected nature of the results obtained from the PPCC, the results of this one test may not be representative of the material. If this material were a serious contender for selection as the repair material, additional testing would be necessary to confirm the present results or to determine the cause of the anomaly. However, since use of a PPCC has been essentially decided against because of its high cost per cubic yard, additional testing does not seem justified. The use of either a PC, which would contain no portland cement, or a PIC would also be prohibitively expensive based upon anticipated material and labor costs.

\section{$\underline{\text { Recommendations }}$}

57. There are three options which currently appear to be available to the District.

a. Use a better quality aggregate with an abrasionerosion resistance similar to that of the reference chert or the Iron Mountain traprock. Use of such an aggregate would permit use of essentially a conventional concrete mixture. Minimum testing would be required to develop final concrete mixture proportions.

b. Use the local limestone aggregate in conjunction with silica fume and high-range water-reducing admixtures to develop a high-strength (approximately 15,000-psi) 
concrete with abrasion-erosion resistance at least as good as the chert reference concrete. This approach would involve additional laboratory testing to develop the concrete mixture proportions. This option would result in field placements requiring a high level of control and inspection.

c. Use a better aggregate to develop a silica-fume concrete. This approach would involve approximately the same degree of testing as item $b$ and would present the same requirement for control and inspection during the field placements.

58. Selection of one of the above options will lead to a concrete with a resistance to abrasion-erosion much better than that of the fiberreinforced concrete. Selection of either option b or c could lead to a concrete with an abrasion resistance comparable to that of PC, PIC, or PPCC, at a much lower cost. 


\section{REFERENCES}

American Concrete Institute Committee 318. 1977. Building Code Requirements for Reinforced Concrete (ACI 318-77), American Concrete Institute, Detroit, Mich.

Engineering News-Record. 1980. "Concrete Mix Adds Strength," Vo1 205, No. 21 , pp 25-26.

Liu, Tony C. 1980. "Maintenance and Preservation of Concrete Structures; Abrasion-Erosion Resistance of Concrete," Technical Report C-78-4, Report 3, U. S. Army Engineer Waterways Experiment Station, Vicksburg, Miss.

McDonald, James E. 1980. "Maintenance and Preservation of Concrete Structures; Repair of Erosion Damaged Structures," Technical Report C-78-4, Report 2, U. S. Army Engineer Waterways Experiment Station, Vicksburg, Miss.

Nawy, E. G., Ukadike, M. M., and Sauer, J. A. 1978. "Optimum Polymer Content in Concrete Modified by Liquid Epoxy Resins," Polymers in Concrete, Special Publication 58, American Concrete Institute, Detroit, Mich.

Office of the Chief of Engineers. 1978. "Civil Works Construction Guide Specification: Concrete," CW-03305, Washington, D. C.

Sauer, J. A., Nawy, E. G., Sun, P. F., and Cook, C. 1975. "Strength Improvements in Mortar and Concrete by Addition of Epoxies," presented at the IV Interamerican Conference on Materials Technology, 29 Jun-4 Jul, Caracas, Venezuela.

U. S. Army Engineer Waterways Experiment Station. 1949. Handbook for Concrete and Cement (with quarterly supplements), Vicksburg, Miss.

1953. "Test Data, Concrete Aggregates in the Continental United States" (with periodic supplements), Technical Memorandum No. 6370, Vicksburg, Miss. 
Table 1. Fine Aggregate Data.

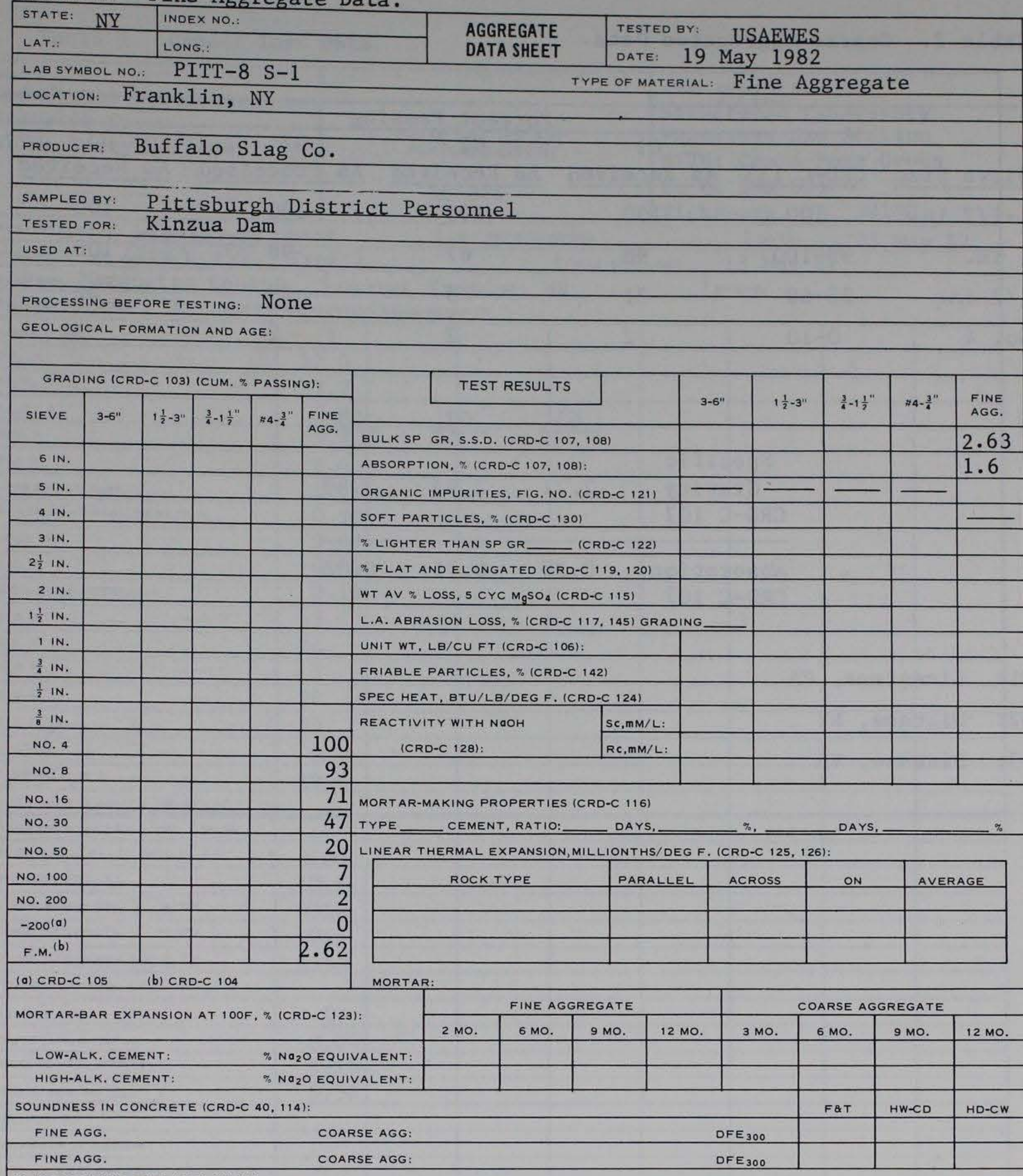

PETROGRAPHIC DATA (CRD-C 127):

AARSE AGG 
Table 2. Coarse Aggregates Data.

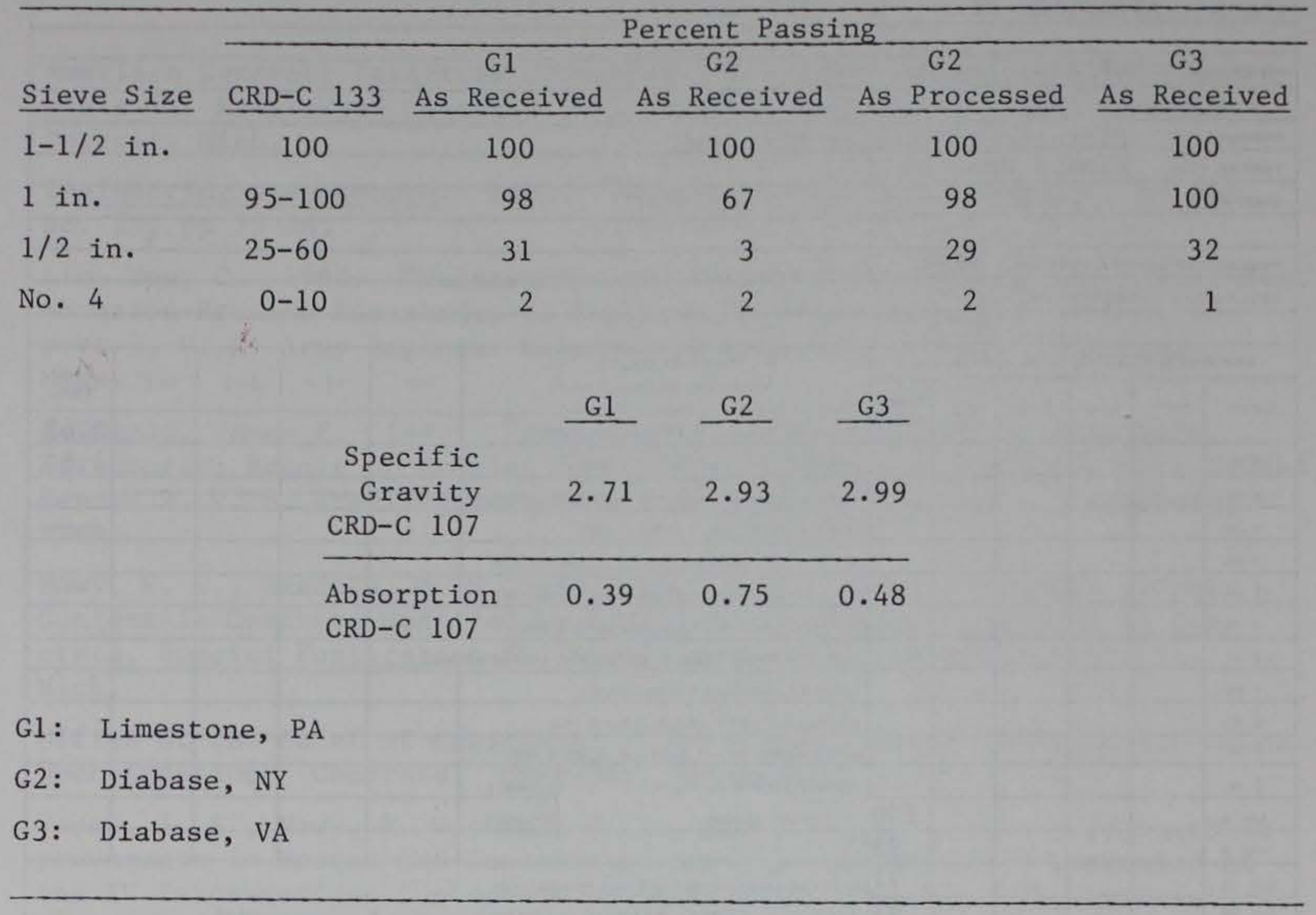


Table 3. Cement Test Data.

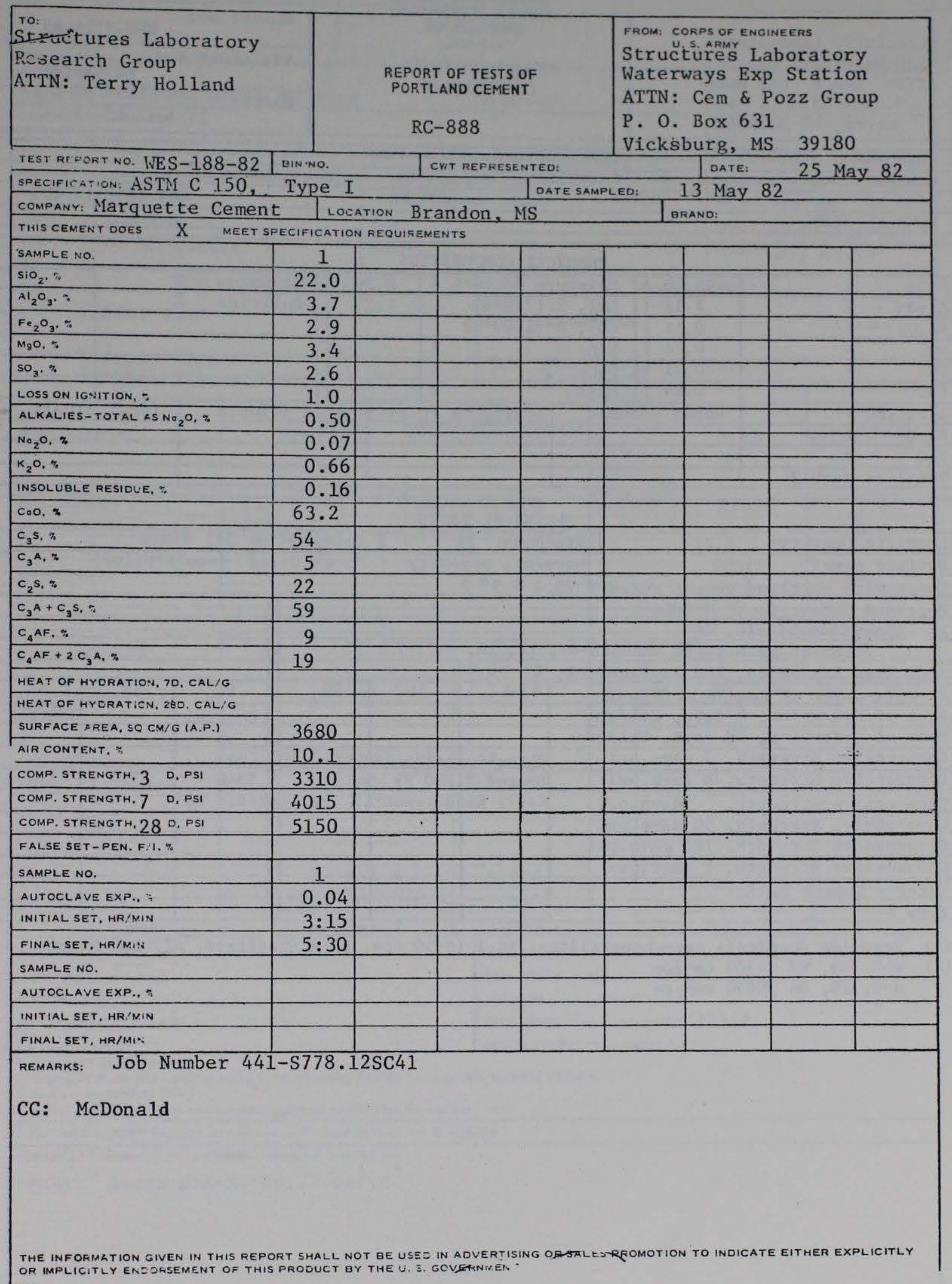


Table 4. Silica-Fume Data.

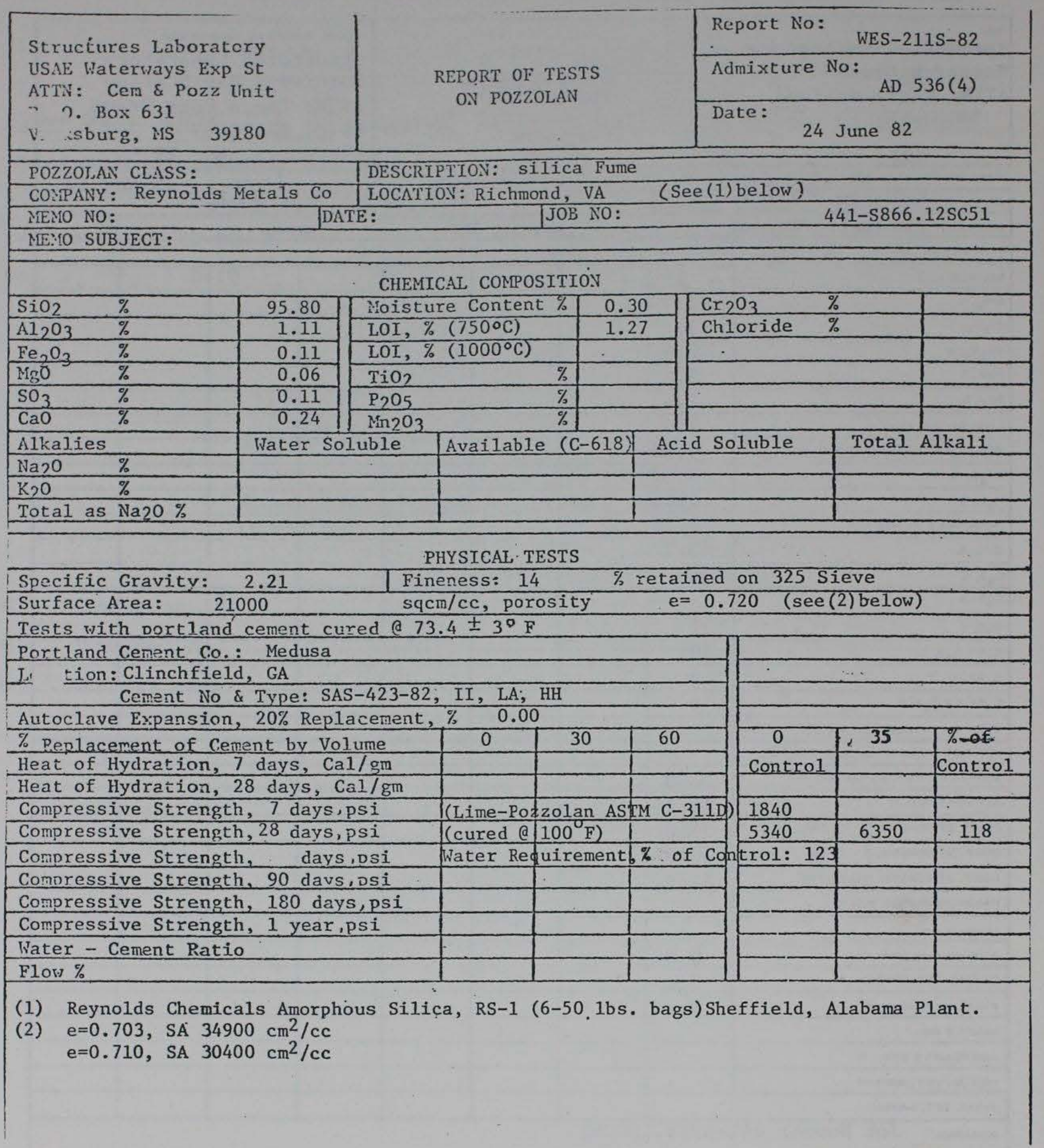


Table 5. Mixture Proportions, Kinzua G1.

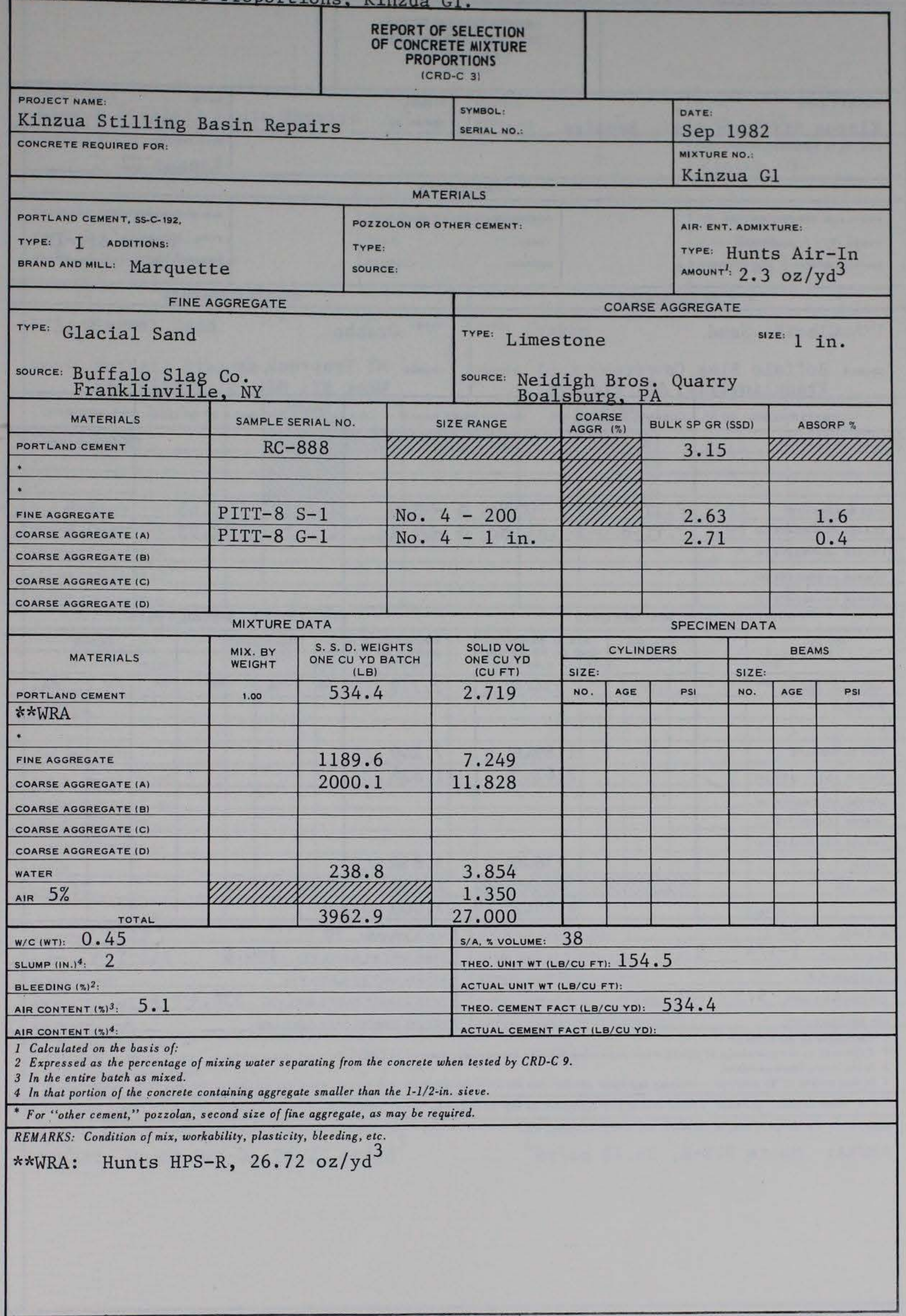


Table 6. Mixture Proportiops, Kinzua G2.

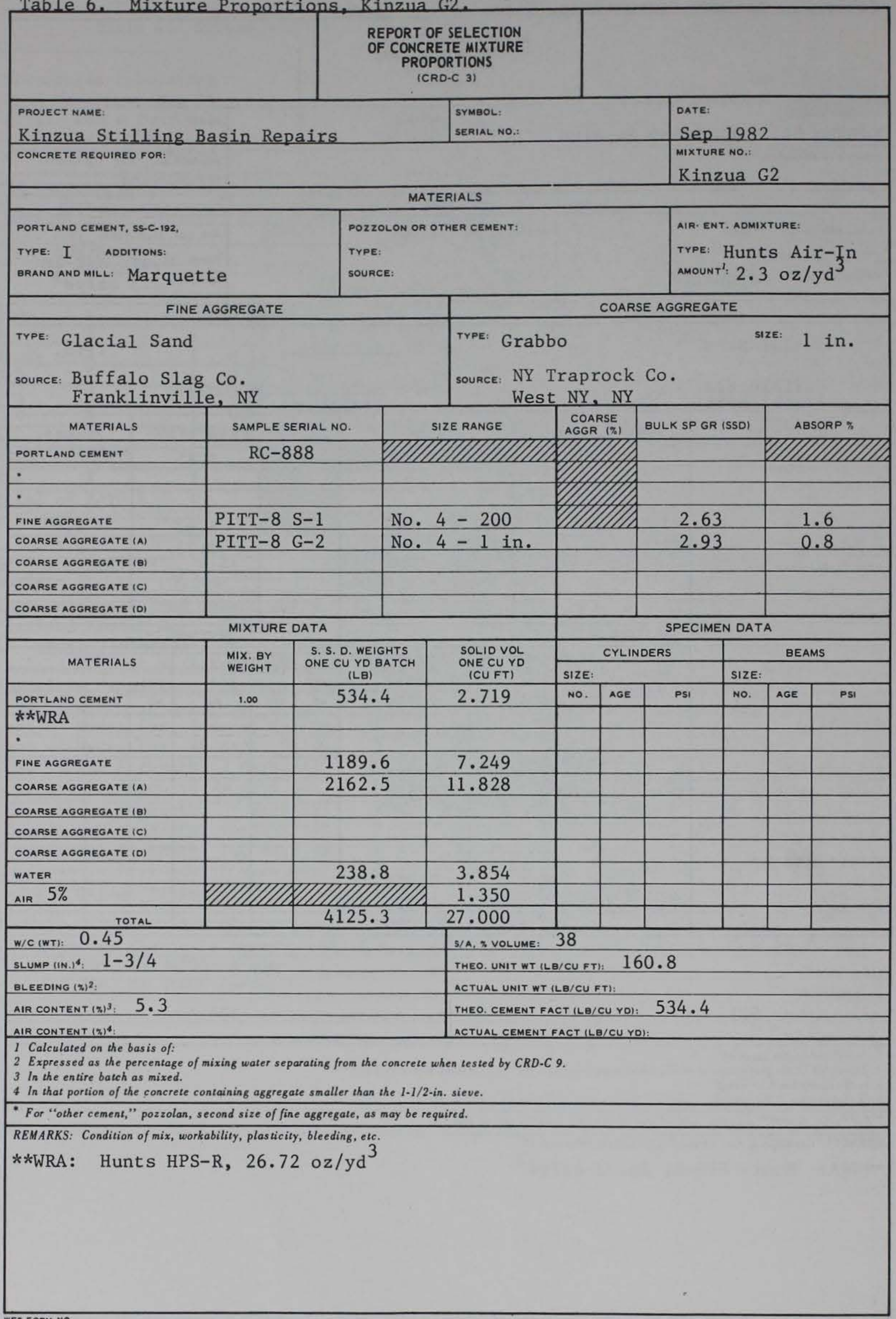


Table 7. Mixture Proportions, Kinzua G3.

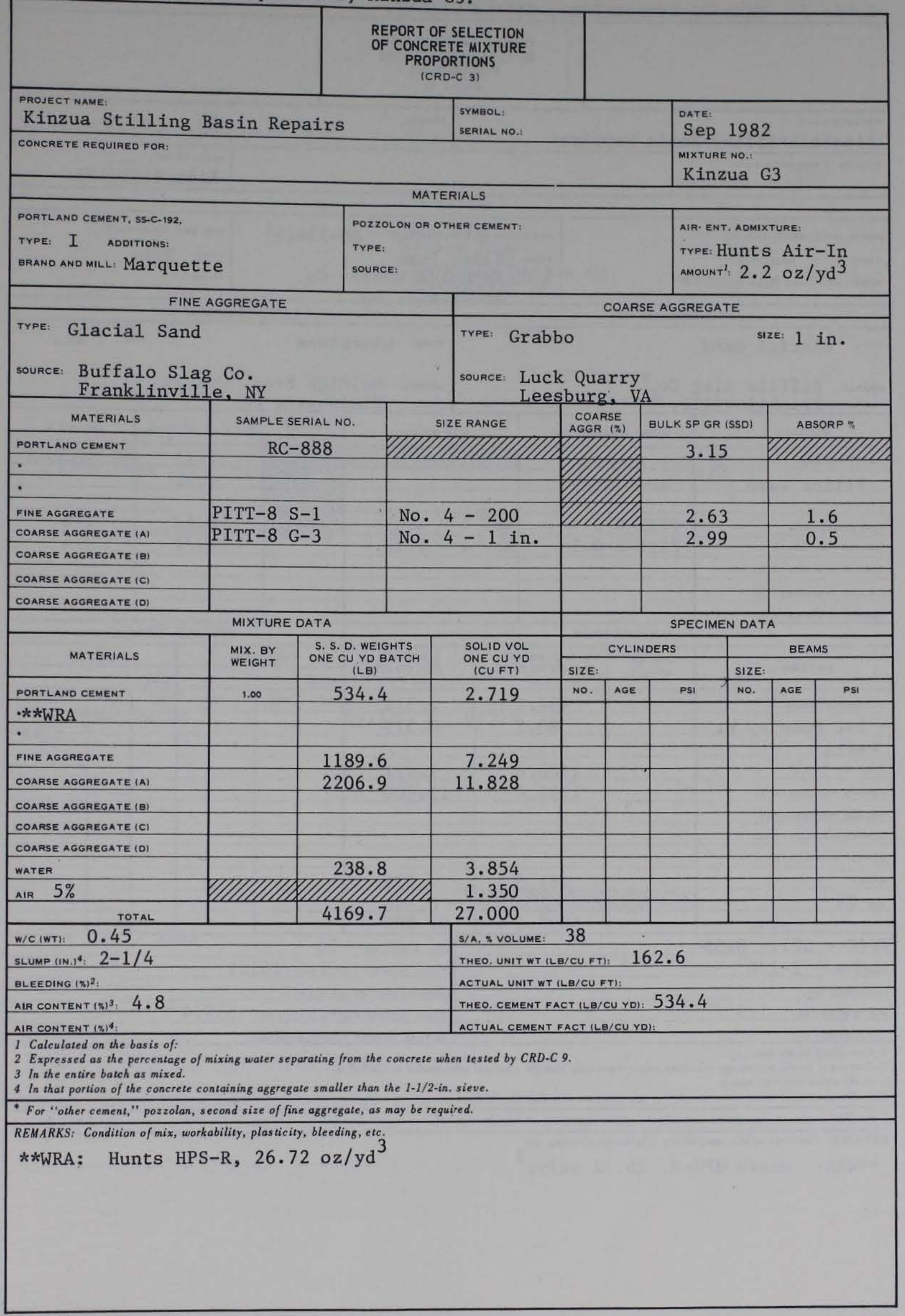


Table 8. Mixture Proportions, Kinzua Gl(SF).

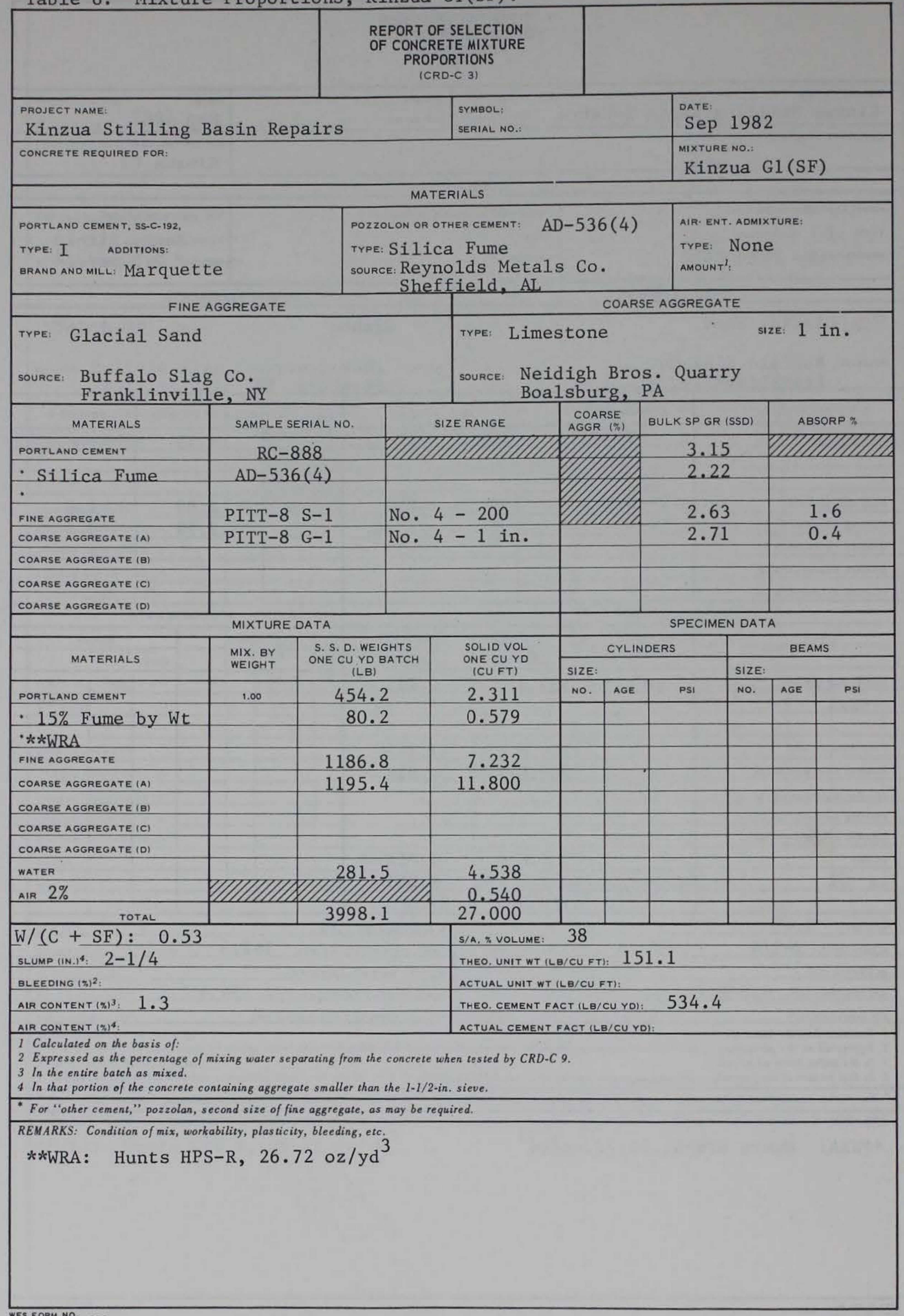


Table 9. Mixture Proportions, Kinzua G3(SF).

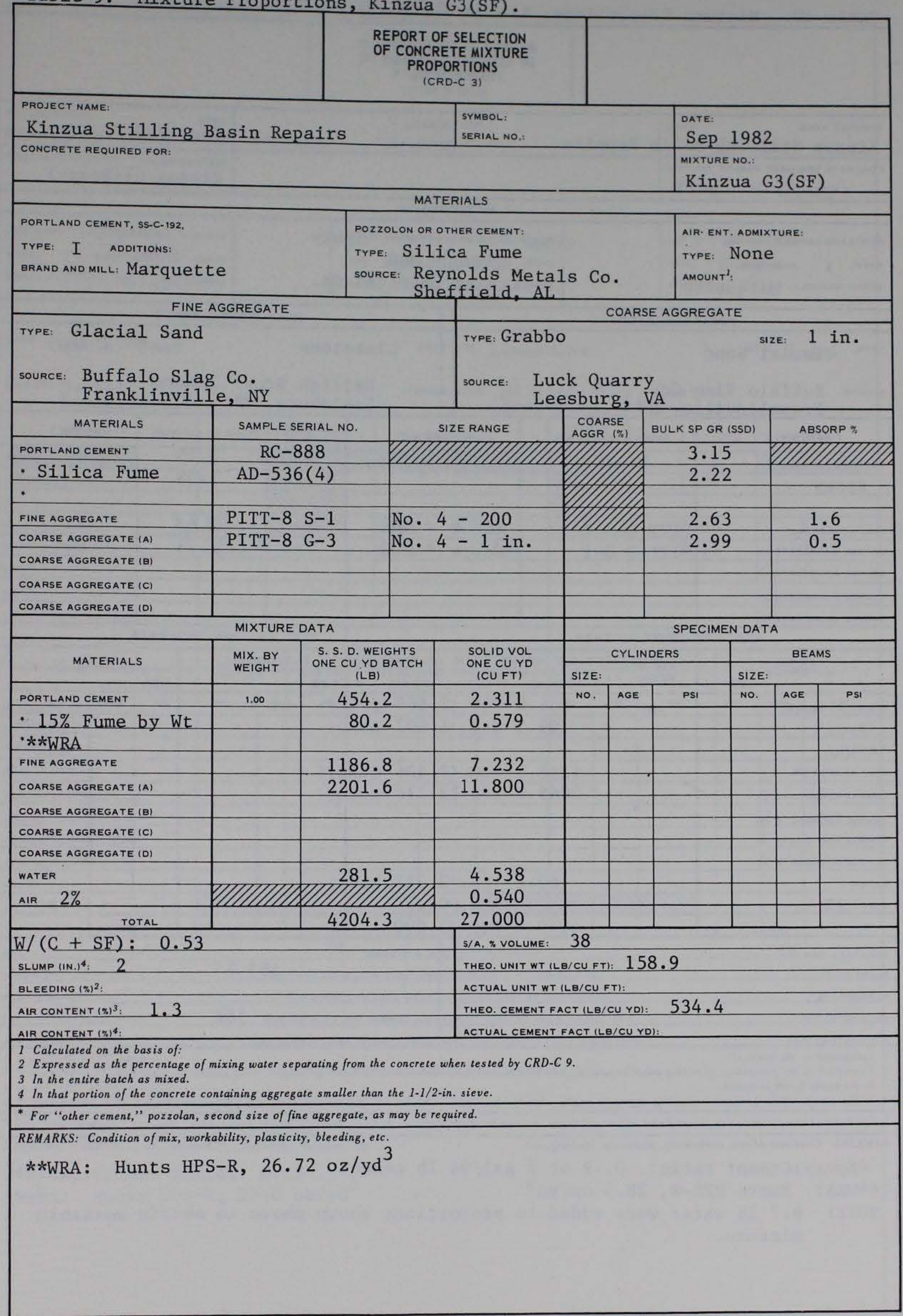


Table 10. Mixture Proportions, Kinzua G1(Epoxy).

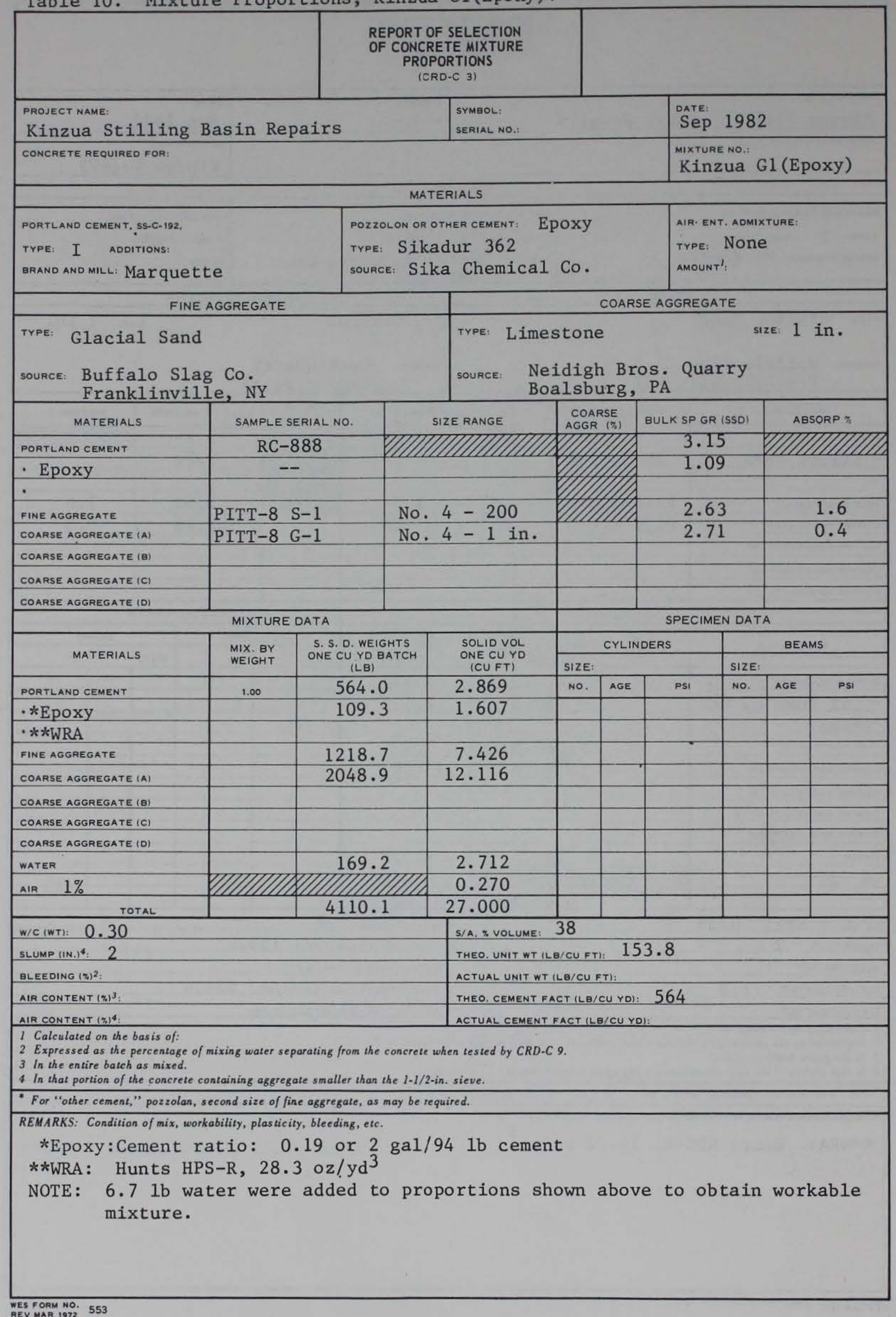


Table 10A. Mixture Proportions, Kinzua.

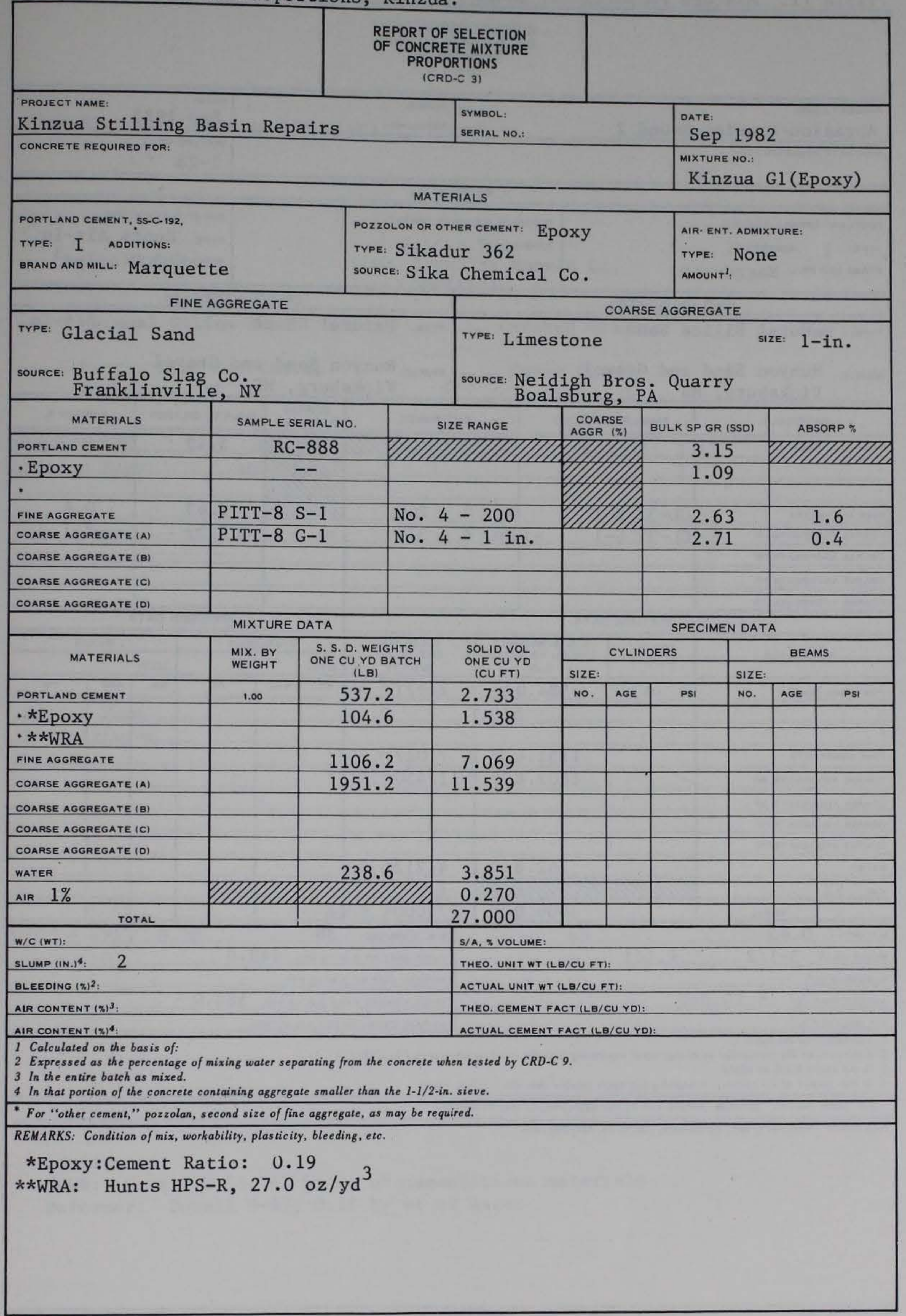


Table 11. Mixture Proportions, Chert Concrete.

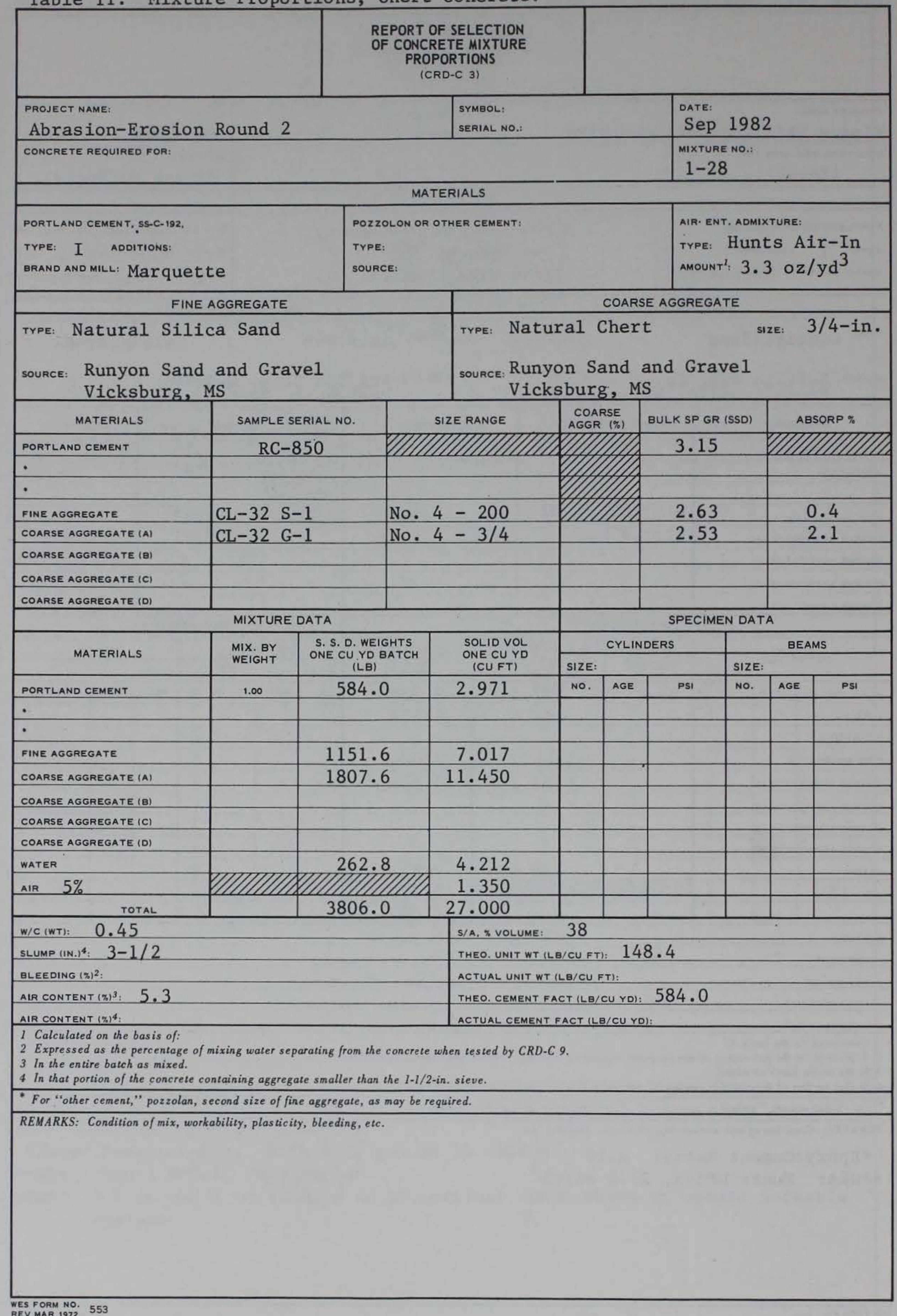


Table 12. Mixture Proportions, Silica Fume 1.

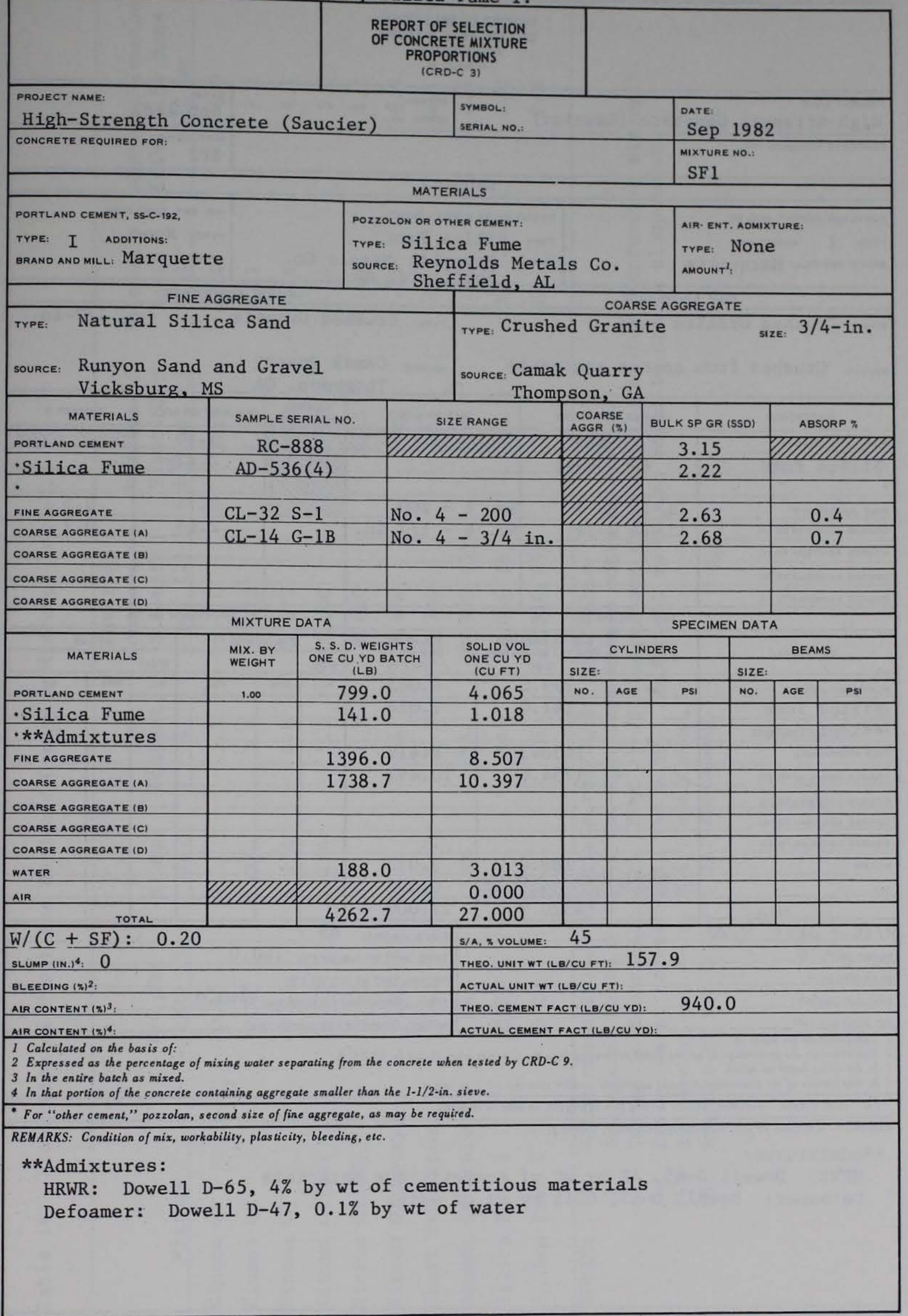


Table 13. Mixture Proportions, Silica Fume 2.

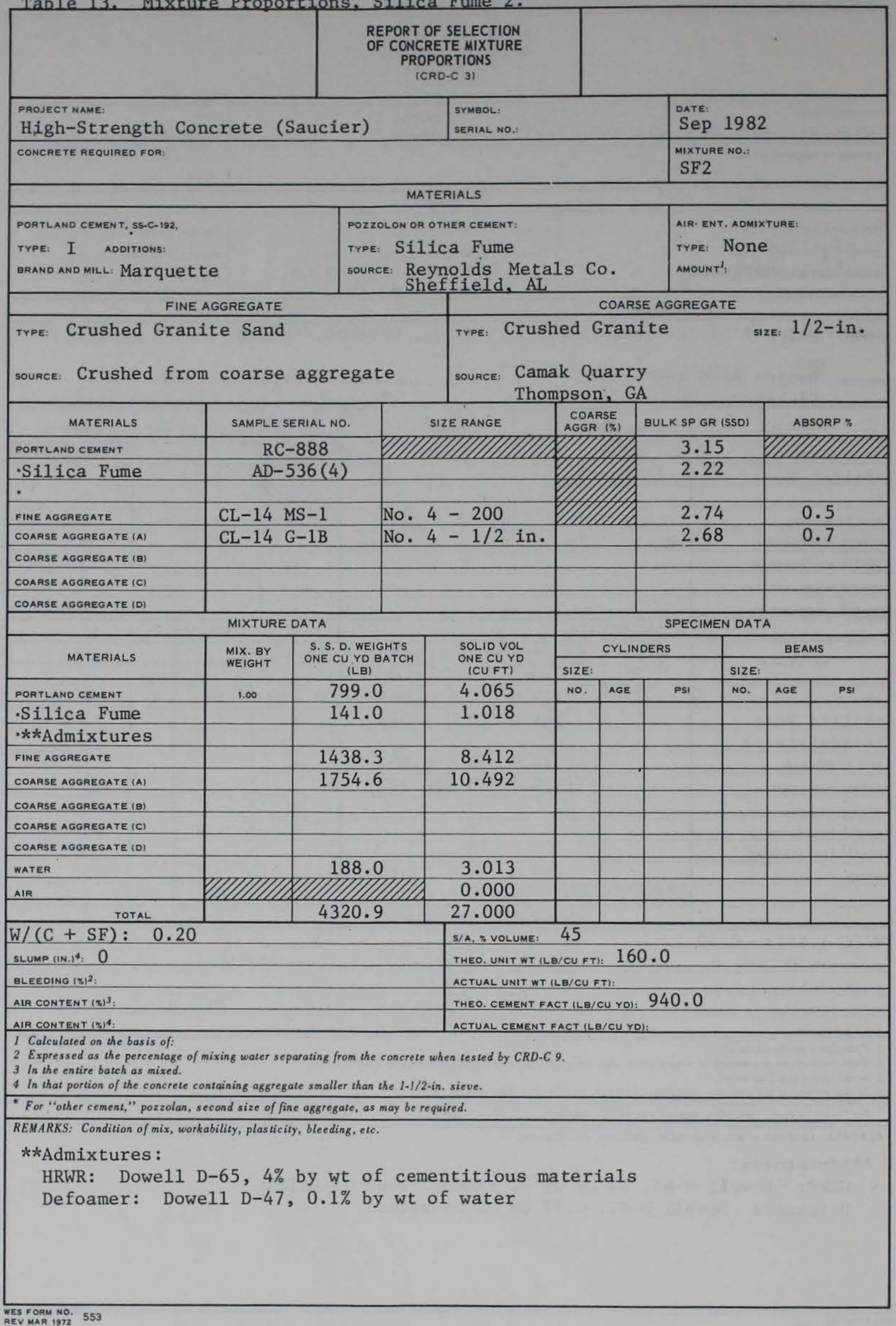


Table 14. Properties of Fresh and Hardened Concrete Mixtures Tested.

\begin{tabular}{|c|c|c|c|c|c|c|c|}
\hline Mixture & $\begin{array}{l}\text { W/C (by } \\
\text { Weight) (1) }\end{array}$ & $\begin{array}{c}\text { Slump, } \\
\text { in. }\end{array}$ & $\begin{array}{c}\text { Air } \\
\text { Content, } \\
\% \\
\end{array}$ & $\begin{array}{c}\text { Average } \\
\text { Compressive } \\
\text { Strength } \\
\text { psi (2) } \\
\end{array}$ & $\begin{array}{l}\text { Modulus of } \\
\text { Elasticity } \\
10^{6} \text { psi (3) } \\
\end{array}$ & $\begin{array}{c}\text { Poisson's } \\
\text { Ratio } \\
\text { (3) } \\
\end{array}$ & $\begin{array}{c}\text { Abrasion-Erosion } \\
\text { Loss, \% by Mass } \\
\text { e } 72 \mathrm{hr} \\
\end{array}$ \\
\hline Kinzua G1 & 0.45 & 2 & 5.1 & 5,710 & 5.25 & 0.24 & 6.9 \\
\hline Kinzua G2 & 0.45 & $1-3 / 4$ & 5.3 & 5,910 & 5.05 & 0.21 & 7.7 \\
\hline Kinzua G3 & 0.45 & $2-1 / 4$ & 4.8 & 5,670 & 5.00 & 0.19 & 6.1 \\
\hline Kinzua G1 (SF) & 0.53 & $2-1 / 4$ & 1.3 & 7,180 & 4.90 & 0.24 & 5.0 \\
\hline Kinzua G3 (SF) & 0.53 & 2 & 1.3 & 8,480 & 5.15 & 0.19 & 4.3 \\
\hline Kinzua Gl (Epoxy) & $0.30(4)$ & 2 & NA & 4,370 & 3.80 & 0.23 & 6.9 \\
\hline Chert Reference & 0.45 & $3-1 / 2$ & 5.3 & 4,740 & NA & NA & 4.1 \\
\hline Densit Concrete & NA & NA & NA & $24,900 \quad(5)$ & 8.30 & 0.21 & 0.5 \\
\hline Silica Fume 1 & 0.20 & 0 & NA & $14,010(6)$ & NA & NA & 2.0 \\
\hline Silica Fume 2 & 0.20 & 0 & NA & $12,910(6)$ & $\mathrm{NA}$ & NA & 1.3 \\
\hline
\end{tabular}

NOTES: (1) Water: cementitious materials ratio, if applicable.

(2) Average of three 6- by 12-in. specimens unless noted otherwise.

(3) Tested in accordance with CRD-C 19-75, using same cylinders tested for compressive strength.

(4) Design water:cement ratio was 0.30. Additional water was added to obtain slump shown.

(5) Average of two 4- by 8-in. specimens.

(6) Average of two $3-$ by 6-in. specimens. 
Table 15. Abrasion-Erosion Test Data.

Concrete mixture: Kinzua G-1

\begin{tabular}{|c|c|c|c|c|c|c|c|}
\hline \multirow{3}{*}{$\begin{array}{c}\text { elapsed } \\
\text { test time } \\
\text { hours } \\
\end{array}$} & \multicolumn{6}{|c|}{ SPECIMEN } & \multirow{3}{*}{$\begin{array}{c}\text { average } \\
\text { percent } \\
\text { loss } \\
\end{array}$} \\
\hline & \multicolumn{2}{|r|}{ A } & \multicolumn{2}{|c|}{ B } & \multicolumn{2}{|c|}{ C } & \\
\hline & $\begin{array}{l}\text { wt, } \\
1 \mathrm{~b}\end{array}$ & $\begin{array}{l}\text { percent } \\
\text { loss }\end{array}$ & $\begin{array}{l}\text { wt, } \\
1 \mathrm{~b}\end{array}$ & $\begin{array}{l}\text { percent } \\
\text { loss }\end{array}$ & $\begin{array}{l}\text { wt, } \\
1 b\end{array}$ & $\begin{array}{l}\text { percent } \\
\text { loss } \\
\end{array}$ & \\
\hline 0 & 38.30 & 0.0 & 38.50 & 0.0 & 38.70 & 0.0 & 0.0 \\
\hline 12 & 37.80 & 1.3 & 38.10 & 1.0 & 38.20 & 1.3 & 1.2 \\
\hline 24 & 37.30 & 2.6 & 37.50 & 2.6 & 37.85 & 2.2 & 2.5 \\
\hline 36 & 36.80 & 3.9 & 37.10 & 3.6 & 37.50 & 3.1 & 3.5 \\
\hline 48 & 36.30 & 5.2 & 36.80 & 4.4 & 37.00 & 4.4 & 4.7 \\
\hline 60 & 35.80 & 6.5 & 36.30 & 5.7 & 36.55 & 5.6 & 5.9 \\
\hline 72 & 35.40 & 7.6 & 36.00 & 6.5 & 36.20 & 6.5 & 6.9 \\
\hline
\end{tabular}

Table 16. Abrasion-Erosion Test Data.

Concrete mixture: Kinzua G-2

\begin{tabular}{|c|c|c|c|c|c|c|c|}
\hline \multirow{3}{*}{$\begin{array}{c}\text { elapsed } \\
\text { test time } \\
\text { hours } \\
\end{array}$} & \multicolumn{6}{|c|}{ SPEC IMEN } & \multirow{3}{*}{$\begin{array}{c}\text { average } \\
\text { percent } \\
\text { loss }\end{array}$} \\
\hline & \multicolumn{2}{|r|}{ A } & \multicolumn{2}{|c|}{ B } & \multicolumn{2}{|c|}{ C } & \\
\hline & $\begin{array}{l}\text { wt, } \\
1 \mathrm{~b}\end{array}$ & $\begin{array}{l}\text { percent } \\
\text { loss }\end{array}$ & $\begin{array}{l}\text { wt, } \\
1 \mathrm{~b}\end{array}$ & $\begin{array}{l}\text { percent } \\
\text { loss }\end{array}$ & $\begin{array}{l}\text { wt, } \\
1 \mathrm{~b}\end{array}$ & $\begin{array}{l}\text { percent } \\
\text { loss }\end{array}$ & \\
\hline 0 & 40.10 & 0.0 & 39.70 & 0.0 & 39.60 & 0.0 & 0.0 \\
\hline 12 & 39.30 & 2.0 & 39.10 & 1.5 & 39.05 & 1.4 & 1.6 \\
\hline 24 & 38.90 & 3.0 & 38.60 & 2.8 & 38.50 & 2.8 & 2.9 \\
\hline 36 & 38.50 & 4.0 & 38.10 & 4.0 & 37.90 & 4.3 & 4.1 \\
\hline 48 & 37.95 & 5.4 & 37.60 & 5.3 & 37.40 & 5.6 & 5.4 \\
\hline 60 & 37.40 & 6.7 & 37.10 & 6.5 & 36.90 & 6.8 & 6.7 \\
\hline 72 & 37.00 & 7.7 & 36.70 & 7.6 & 36.50 & 7.8 & 7.7 \\
\hline
\end{tabular}


Table 17. Abrasion-Erosion Test Data.

Concrete mixture: Kinzua G-3

\begin{tabular}{|c|c|c|c|c|c|c|c|}
\hline \multirow{3}{*}{$\begin{array}{c}\text { elapsed } \\
\text { test time } \\
\text { hours } \\
\end{array}$} & \multicolumn{6}{|c|}{ SPECIMEN } & \multirow{3}{*}{$\begin{array}{c}\text { average } \\
\text { percent } \\
\text { loss } \\
\end{array}$} \\
\hline & \multicolumn{2}{|r|}{ A } & \multicolumn{2}{|c|}{ B } & \multicolumn{2}{|c|}{ C } & \\
\hline & $\begin{array}{l}w t, \\
1 b\end{array}$ & $\begin{array}{l}\text { percent } \\
\text { loss }\end{array}$ & $\begin{array}{l}\text { wt, } \\
1 \mathrm{~b}\end{array}$ & $\begin{array}{l}\text { percent } \\
\text { loss }\end{array}$ & $\begin{array}{l}\text { wt, } \\
1 \mathrm{~b}\end{array}$ & $\begin{array}{l}\text { percent } \\
\text { loss }\end{array}$ & \\
\hline 0 & 40.25 & 0.0 & 40.70 & 0.0 & 40.50 & 0.0 & 0.0 \\
\hline 12 & 39.70 & 1.4 & 40.05 & 1.6 & 39.95 & 1.4 & 1.5 \\
\hline 24 & 39.15 & 2.7 & 39.55 & 2.8 & 39.45 & 2.6 & 2.7 \\
\hline 36 & 38.70 & 3.9 & 39.15 & 3.8 & 39.10 & 3.5 & 3.7 \\
\hline 48 & 38.30 & 4.8 & 38.85 & 4.5 & 38.70 & 4.4 & 4.6 \\
\hline 60 & 37.95 & 5.7 & 38.60 & 5.2 & 38.40 & 5.2 & 5.4 \\
\hline 72 & 37.60 & 6.6 & 38.30 & 5.9 & 38.10 & 5.9 & 6.1 \\
\hline
\end{tabular}

Table 18. Abrasion-Erosion Test Data.

Concrete mixture: G1 (Silica Fume)

\begin{tabular}{|c|c|c|c|c|c|c|c|}
\hline \multirow{3}{*}{$\begin{array}{c}\text { elapsed } \\
\text { test time } \\
\text { hours } \\
\end{array}$} & \multicolumn{6}{|c|}{ SPECIMEN } & \multirow{3}{*}{$\begin{array}{c}\text { average } \\
\text { percent } \\
\text { loss } \\
\end{array}$} \\
\hline & \multicolumn{2}{|r|}{$\mathrm{A}$} & \multicolumn{2}{|c|}{ B } & \multicolumn{2}{|c|}{ C } & \\
\hline & $\begin{array}{l}\text { wt, } \\
1 \mathrm{~b}\end{array}$ & $\begin{array}{l}\text { percent } \\
\text { loss }\end{array}$ & $\begin{array}{l}\mathrm{wt}, \\
1 \mathrm{~b}\end{array}$ & $\begin{array}{l}\text { percent } \\
\text { loss }\end{array}$ & $\begin{array}{l}\mathrm{wt}, \\
1 \mathrm{~b}\end{array}$ & $\begin{array}{l}\text { percent } \\
\text { loss }\end{array}$ & \\
\hline 0 & 39.30 & 0.0 & 39.85 & 0.0 & 38.50 & 0.0 & 0.0 \\
\hline 12 & 38.30 & $N G *$ & 38.80 & NG* & 37.50 & $N G *$ & NG* \\
\hline 24 & 38.60 & 1.8 & 39.05 & 2.0 & 37.75 & 1.9 & 1.9 \\
\hline 36 & 38.15 & 2.9 & 38.65 & 3.0 & 37.30 & 3.1 & 3.0 \\
\hline 48 & 37.90 & 3.6 & 38.40 & 3.6 & 36.85 & 4.3 & 3.8 \\
\hline 60 & 37.60 & 4.3 & 38.15 & 4.3 & NG** & -- & 4.3 \\
\hline 72 & 37.30 & 5.1 & 37.90 & 4.9 & NG** & -- & 5.0 \\
\hline
\end{tabular}

Notes: * Weights incorrect - scale not set at zero.

** Timer failed during run. 
Table 19. Abrasion-Erosion Test Data.

Concrete mixture: G3 (Silica Fume)

\begin{tabular}{|c|c|c|c|c|c|c|c|}
\hline \multirow{3}{*}{$\begin{array}{c}\text { elapsed } \\
\text { test time } \\
\text { hours } \\
\end{array}$} & \multicolumn{6}{|c|}{ SPECIMEN } & \multirow{3}{*}{$\begin{array}{c}\text { average } \\
\text { percent } \\
\text { loss }\end{array}$} \\
\hline & \multicolumn{2}{|r|}{ A } & \multicolumn{2}{|c|}{ B } & \multicolumn{2}{|c|}{$\mathrm{C}$} & \\
\hline & $\begin{array}{l}\text { wt, } \\
1 \mathrm{~b}\end{array}$ & $\begin{array}{l}\text { percent } \\
\text { loss }\end{array}$ & $\begin{array}{l}w t, \\
1 \mathrm{~b}\end{array}$ & $\begin{array}{l}\text { percent } \\
\text { loss }\end{array}$ & $\begin{array}{l}\text { wt, } \\
1 \mathrm{~b}\end{array}$ & $\begin{array}{l}\text { percent } \\
\text { loss }\end{array}$ & \\
\hline 0 & 38.40 & 0.0 & 40.90 & 0.0 & 41.85 & 0.0 & 0.0 \\
\hline 12 & 38.10 & 0.8 & 40.50 & 1.0 & 41.45 & 1.0 & 0.9 \\
\hline 24 & 37.90 & 1.3 & 40.10 & 2.0 & 41.20 & 1.6 & 1.6 \\
\hline 36 & 37.60 & 2.1 & 39.75 & 2.8 & 40.75 & 2.6 & 2.5 \\
\hline 48 & 37.35 & 2.7 & 39.50 & 3.4 & 40.55 & 3.1 & 3.1 \\
\hline 60 & 37.00 & 3.6 & 39.20 & 4.2 & 40.30 & 3.7 & 3.8 \\
\hline 72 & 36.80 & 4.2 & 39.00 & 4.6 & 40.10 & 4.2 & 4.3 \\
\hline
\end{tabular}

Table 20. Abrasion-Erosion Test Data.

Concrete mixture: Kinzua G1(Epoxy)

\begin{tabular}{|c|c|c|c|c|c|c|c|}
\hline \multirow{3}{*}{$\begin{array}{l}\text { elapsed } \\
\text { test time } \\
\text { hours }\end{array}$} & \multicolumn{6}{|c|}{ SPECIMEN } & \multirow{3}{*}{$\begin{array}{c}\text { average } \\
\text { percent } \\
\text { loss }\end{array}$} \\
\hline & \multicolumn{2}{|r|}{ A } & \multicolumn{2}{|c|}{ B } & \multicolumn{2}{|c|}{$\mathrm{C}$} & \\
\hline & $\begin{array}{l}w t, \\
1 b\end{array}$ & $\begin{array}{l}\text { percent } \\
\text { loss }\end{array}$ & $\begin{array}{l}w t, \\
1 b\end{array}$ & $\begin{array}{l}\text { percent } \\
\text { loss }\end{array}$ & $\begin{array}{l}\mathrm{wt}, \\
1 \mathrm{~b}\end{array}$ & $\begin{array}{l}\text { percent } \\
\text { loss }\end{array}$ & \\
\hline 0 & 37.80 & 0.0 & 38.35 & 0.0 & 38.00 & 0.0 & 0.0 \\
\hline 12 & 37.20 & 1.6 & 37.70 & 1.7 & 37.70 & 0.8 & 1.4 \\
\hline 24 & 36.80 & 2.6 & 37.30 & 2.7 & 37.35 & 1.7 & 2.3 \\
\hline 36 & 36.40 & 3.7 & 36.95 & 3.7 & 37.00 & 2.6 & 3.3 \\
\hline 48 & 35.90 & 5.0 & 36.45 & 5.0 & 36.60 & 3.7 & 4.6 \\
\hline 60 & 35.50 & 6.1 & 36.00 & 6.1 & 36.35 & 4.3 & 5.5 \\
\hline 72 & 34.75 & 8.1 & 35.60 & 7.2 & 35.90 & 5.5 & 6.9 \\
\hline
\end{tabular}


Table 21. Abrasion-Erosion Test Data.

Concrete mixture: Kinzua Cores

\begin{tabular}{|c|c|c|c|c|c|c|c|}
\hline \multirow{3}{*}{$\begin{array}{c}\text { elapsed } \\
\text { test time } \\
\text { hours } \\
\end{array}$} & \multicolumn{6}{|c|}{ SPECIMEN } & \multirow{3}{*}{$\begin{array}{c}\text { average } \\
\text { percent } \\
\text { loss } \\
\end{array}$} \\
\hline & \multicolumn{2}{|r|}{ A } & \multicolumn{2}{|c|}{ B } & \multicolumn{2}{|c|}{ C } & \\
\hline & $\begin{array}{l}\text { wt, } \\
1 \mathrm{~b}\end{array}$ & $\begin{array}{l}\text { percent } \\
\text { loss }\end{array}$ & $\begin{array}{l}w t, \\
1 b\end{array}$ & $\begin{array}{l}\text { percent } \\
\text { loss }\end{array}$ & $\begin{array}{l}\text { wt, } \\
1 \mathrm{~b}\end{array}$ & $\begin{array}{l}\text { percent } \\
\text { loss }\end{array}$ & \\
\hline 0 & 33.40 & 0.0 & 33.40 & 0.0 & 33.20 & 0.0 & 0.0 \\
\hline 12 & 32.90 & 1.5 & 33.00 & 1.2 & 32.80 & 1.2 & 1.3 \\
\hline 24 & 32.30 & 3.3 & 32.60 & 2.4 & 32.20 & 3.0 & 2.9 \\
\hline 36 & 31.85 & 4.6 & 32.30 & 3.3 & 31.50 & 5.1 & 4.3 \\
\hline 48 & 31.10 & 6.9 & 31.90 & 4.5 & 30.90 & 6.9 & 6.1 \\
\hline 60 & 30.30 & 9.3 & 31.60 & 5.4 & 30.00 & 9.6 & 8.1 \\
\hline 72 & 30.10 & 9.9 & 31.10 & 6.9 & 29.40 & 11.4 & 9.4 \\
\hline
\end{tabular}

Table 22. Abrasion-Erosion Test Data.

Concrete mixture: Chert Reference

\begin{tabular}{|c|c|c|c|c|c|c|c|}
\hline \multirow{3}{*}{$\begin{array}{c}\text { elapsed } \\
\text { test time } \\
\text { hours } \\
\end{array}$} & \multicolumn{6}{|c|}{ SPECIMEN } & \multirow{3}{*}{$\begin{array}{c}\text { average } \\
\text { percent } \\
\text { loss } \\
\end{array}$} \\
\hline & \multicolumn{2}{|r|}{ A } & \multicolumn{2}{|c|}{$\mathrm{B}$} & \multicolumn{2}{|c|}{$\mathrm{C}$} & \\
\hline & $\begin{array}{l}w t, \\
1 b\end{array}$ & $\begin{array}{l}\text { percent } \\
\text { loss }\end{array}$ & $\begin{array}{l}\mathrm{wt}, \\
1 \mathrm{~b}\end{array}$ & $\begin{array}{l}\text { percent } \\
\text { loss } \\
\end{array}$ & $\begin{array}{l}\text { wt, } \\
1 \mathrm{~b}\end{array}$ & $\begin{array}{l}\text { percent } \\
\text { loss }\end{array}$ & \\
\hline 0 & 36.70 & 0.0 & 36.30 & 0.0 & 35.95 & 0.0 & 0.0 \\
\hline 12 & 36.00 & 1.9 & 35.70 & 1.7 & 35.35 & 1.7 & 1.8 \\
\hline 24 & 35.75 & 2.6 & 35.35 & 2.6 & 35.00 & 2.6 & 2.6 \\
\hline 36 & 35.70 & 2.7 & 35.20 & 3.0 & 34.75 & 3.3 & 3.0 \\
\hline 48 & 35.60 & 3.0 & 35.10 & 3.3 & 34.60 & 3.8 & 3.4 \\
\hline 60 & 35.50 & 3.3 & 34.90 & 3.9 & 34.55 & 3.9 & 3.7 \\
\hline 72 & 35.35 & 3.7 & 34.85 & 4.0 & 34.30 & 4.6 & 4.1 \\
\hline
\end{tabular}


Table 23. Abrasion-Erosion Test Data.

Concrete mixture: Densit Concrete

\begin{tabular}{|c|c|c|c|c|c|c|c|}
\hline \multirow{3}{*}{$\begin{array}{c}\text { elapsed } \\
\text { test time } \\
\text { hours } \\
\end{array}$} & \multicolumn{6}{|c|}{ SPECIMEN } & \multirow{3}{*}{$\begin{array}{l}\text { average } \\
\text { percent } \\
\text { loss }\end{array}$} \\
\hline & \multicolumn{2}{|r|}{ A } & \multicolumn{2}{|c|}{ B } & \multicolumn{2}{|c|}{ C } & \\
\hline & $\begin{array}{l}\text { wt, } \\
1 \mathrm{~b}\end{array}$ & $\begin{array}{l}\text { percent } \\
\text { loss }\end{array}$ & $\begin{array}{l}\mathrm{wt}, \\
1 \mathrm{~b}\end{array}$ & $\begin{array}{l}\text { percent } \\
\text { loss }\end{array}$ & $\begin{array}{l}\text { wt, } \\
1 \mathrm{~b}\end{array}$ & $\begin{array}{l}\text { percent } \\
\text { loss }\end{array}$ & \\
\hline 0 & 44.10 & 0.0 & 43.60 & 0.0 & 43.70 & 0.0 & 0.0 \\
\hline 12 & 44.00 & 0.2 & 43.50 & 0.2 & 43.60 & 0.2 & 0.2 \\
\hline 24 & 43.90 & 0.5 & 43.40 & 0.5 & 43.60 & 0.2 & 0.4 \\
\hline 36 & 43.85 & 0.6 & 43.35 & 0.6 & 43.60 & 0.2 & 0.5 \\
\hline 48 & 43.80 & 0.7 & 43.30 & 0.7 & 43.60 & 0.2 & 0.5 \\
\hline 60 & 43.80 & 0.7 & 43.30 & 0.7 & 43.60 & 0.2 & 0.5 \\
\hline 72 & 43.80 & 0.7 & 43.30 & 0.7 & 43.60 & 0.2 & 0.5 \\
\hline
\end{tabular}

Table 24. Abrasion-Erosion Test Data.

Concrete mixture: Silica Fume 1

\begin{tabular}{|c|c|c|c|c|c|c|c|}
\hline \multirow{3}{*}{$\begin{array}{c}\text { elapsed } \\
\text { test time } \\
\text { hours } \\
\end{array}$} & \multicolumn{6}{|c|}{ SPECIMEN } & \multirow{3}{*}{$\begin{array}{c}\text { average } \\
\text { percent } \\
\text { loss } \\
\end{array}$} \\
\hline & \multicolumn{2}{|r|}{ A } & \multicolumn{2}{|c|}{ B } & \multicolumn{2}{|c|}{$\mathrm{C}$} & \\
\hline & $\begin{array}{l}\text { wt, } \\
1 \mathrm{~b}\end{array}$ & $\begin{array}{l}\text { percent } \\
\text { loss }\end{array}$ & $\begin{array}{l}\text { wt, } \\
1 \mathrm{~b}\end{array}$ & $\begin{array}{l}\text { percent } \\
\text { loss }\end{array}$ & $\begin{array}{l}w t, \\
1 b\end{array}$ & $\begin{array}{l}\text { percent } \\
\text { loss }\end{array}$ & \\
\hline 0 & 39.70 & 0.0 & 39.60 & 0.0 & & 0.0 & 0.0 \\
\hline 12 & 39.50 & 0.5 & 39.35 & 0.6 & & & 0.6 \\
\hline 24 & 39.45 & 0.6 & 39.25 & 0.9 & & & 0.8 \\
\hline 36 & 39.30 & 1.0 & 39.10 & 1.3 & & & 1.2 \\
\hline 48 & 39.20 & 1.3 & 39.00 & 1.5 & & & 1.4 \\
\hline 60 & 39.10 & 1.5 & 38.90 & 1.8 & & & 1.7 \\
\hline 72 & 39.00 & 1.8 & 38.75 & 2.1 & & & 2.0 \\
\hline
\end{tabular}


Table 25. Abrasion-Erosion Test Data.

Concrete mixture: Silica Fume 2

\begin{tabular}{|c|c|c|c|c|c|c|c|}
\hline \multirow{3}{*}{$\begin{array}{c}\text { elapsed } \\
\text { test time } \\
\text { hours } \\
\end{array}$} & \multicolumn{6}{|c|}{ SPECIMEN } & \multirow{3}{*}{$\begin{array}{c}\text { average } \\
\text { percent } \\
\text { loss } \\
\end{array}$} \\
\hline & \multicolumn{2}{|r|}{ A } & \multicolumn{2}{|c|}{ B } & \multicolumn{2}{|c|}{ C } & \\
\hline & $\begin{array}{l}\text { wt, } \\
1 \mathrm{~b}\end{array}$ & $\begin{array}{l}\text { percent } \\
\text { loss }\end{array}$ & $\begin{array}{l}\mathrm{wt}, \\
1 \mathrm{~b}\end{array}$ & $\begin{array}{l}\text { percent } \\
\text { loss }\end{array}$ & $\begin{array}{l}\text { wt, } \\
1 b\end{array}$ & $\begin{array}{l}\text { percent } \\
\text { loss }\end{array}$ & \\
\hline 0 & 40.30 & 0.0 & 40.00 & 0.0 & & 0.0 & 0.0 \\
\hline 12 & 40.15 & 0.4 & 39.90 & 0.3 & & & 0.4 \\
\hline 24 & 40.10 & 0.5 & 39.85 & 0.4 & & & 0.5 \\
\hline 36 & 40.00 & 0.7 & 39.85 & 0.4 & & & 0.6 \\
\hline 48 & 40.00 & 0.7 & 39.75 & 0.6 & & & 0.7 \\
\hline 60 & 39.90 & 1.0 & 39.60 & 1.0 & & & 1.0 \\
\hline 72 & 39.75 & 1.4 & 39.55 & 1.1 & & & 1.3 \\
\hline
\end{tabular}




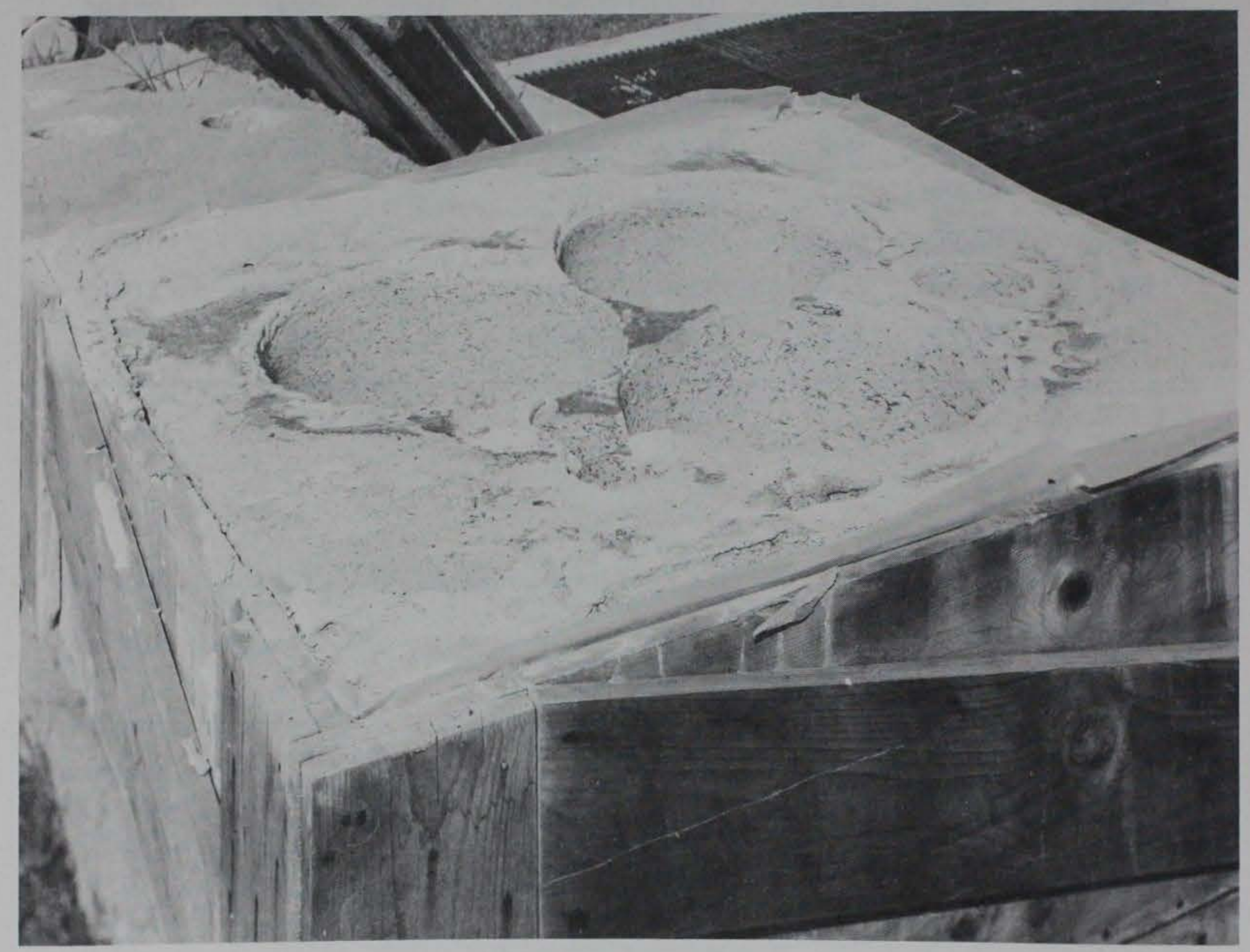

Figure 1. Chunk sample of fiber-reinforced concrete from Kinzua stilling basin after cores were drilled for abrasion-erosion testing. The surface of the sample was leveled using a grout to provide a flat drilling surface. The small holes in the sample are from attempts to take small diameter cores for comparison testing. 


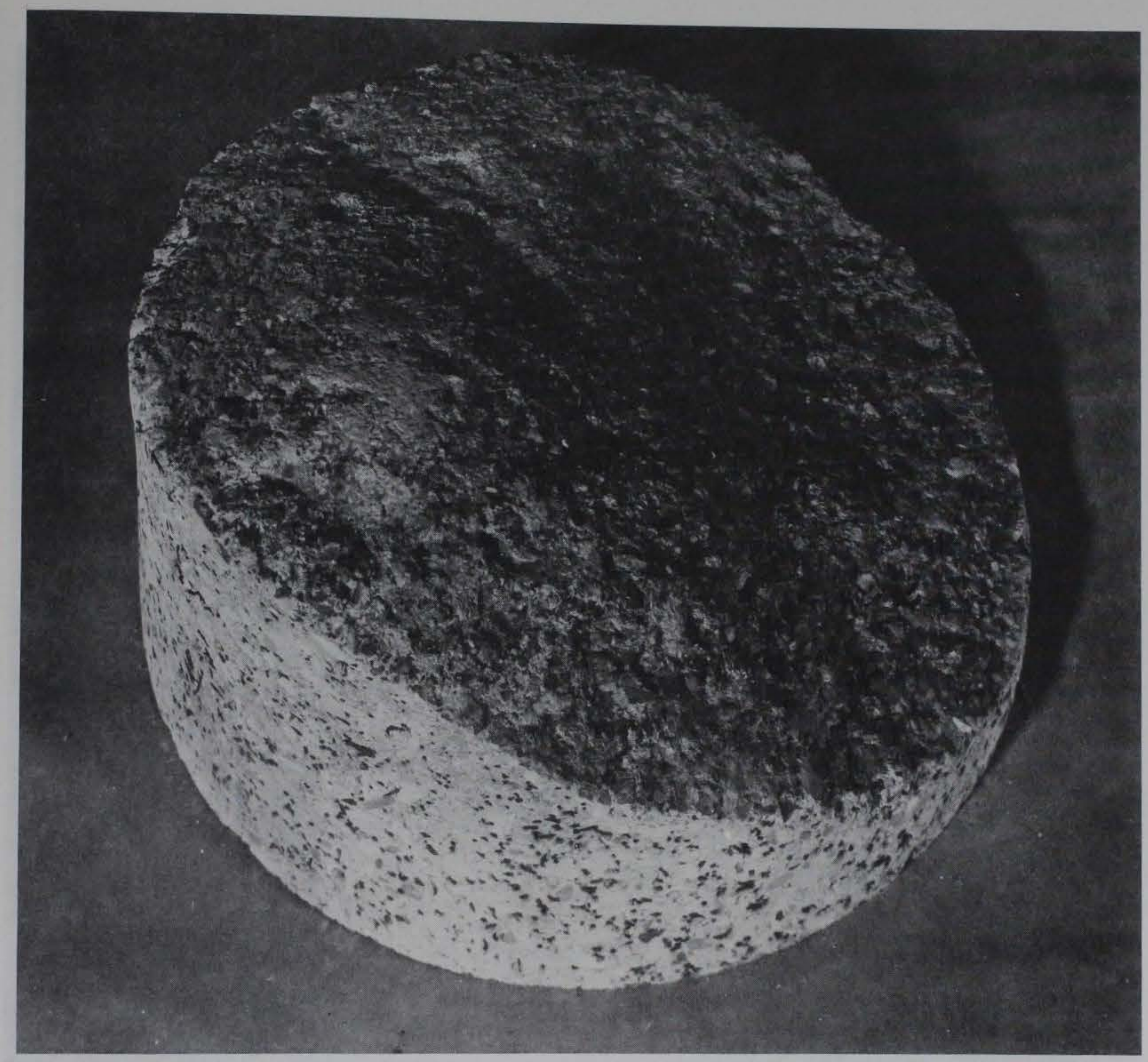

Figure 2. Top portion of large diameter core taken from chunk sample. Specimen for abrasion-erosion testing was sawed from beneath the portion shown. The surface shown is the original wearing surface from the stilling basin. 


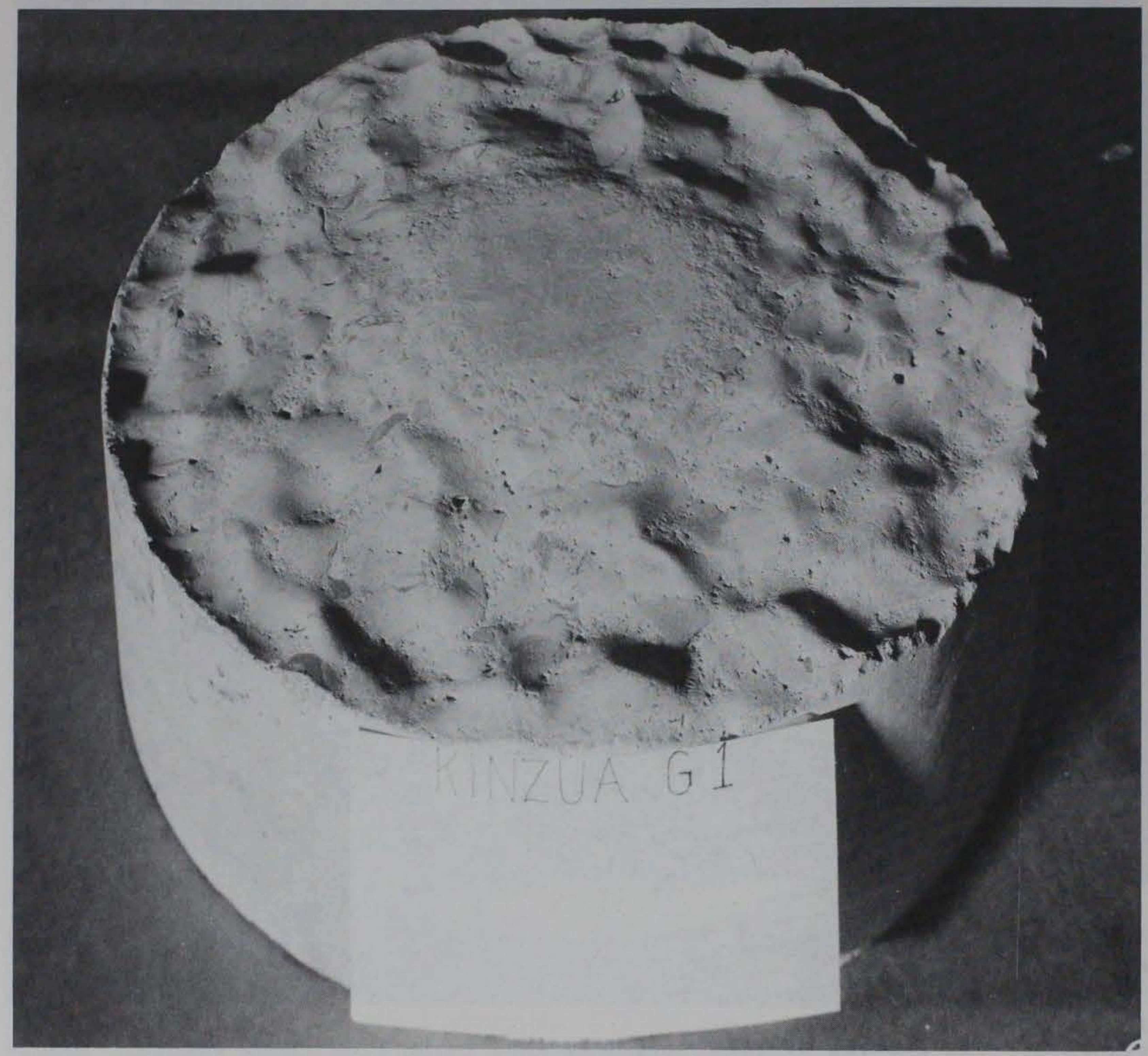

Figure 3. Abrasion-erosion specimen at conclusion of testing, mixture Kinzua Gl. 


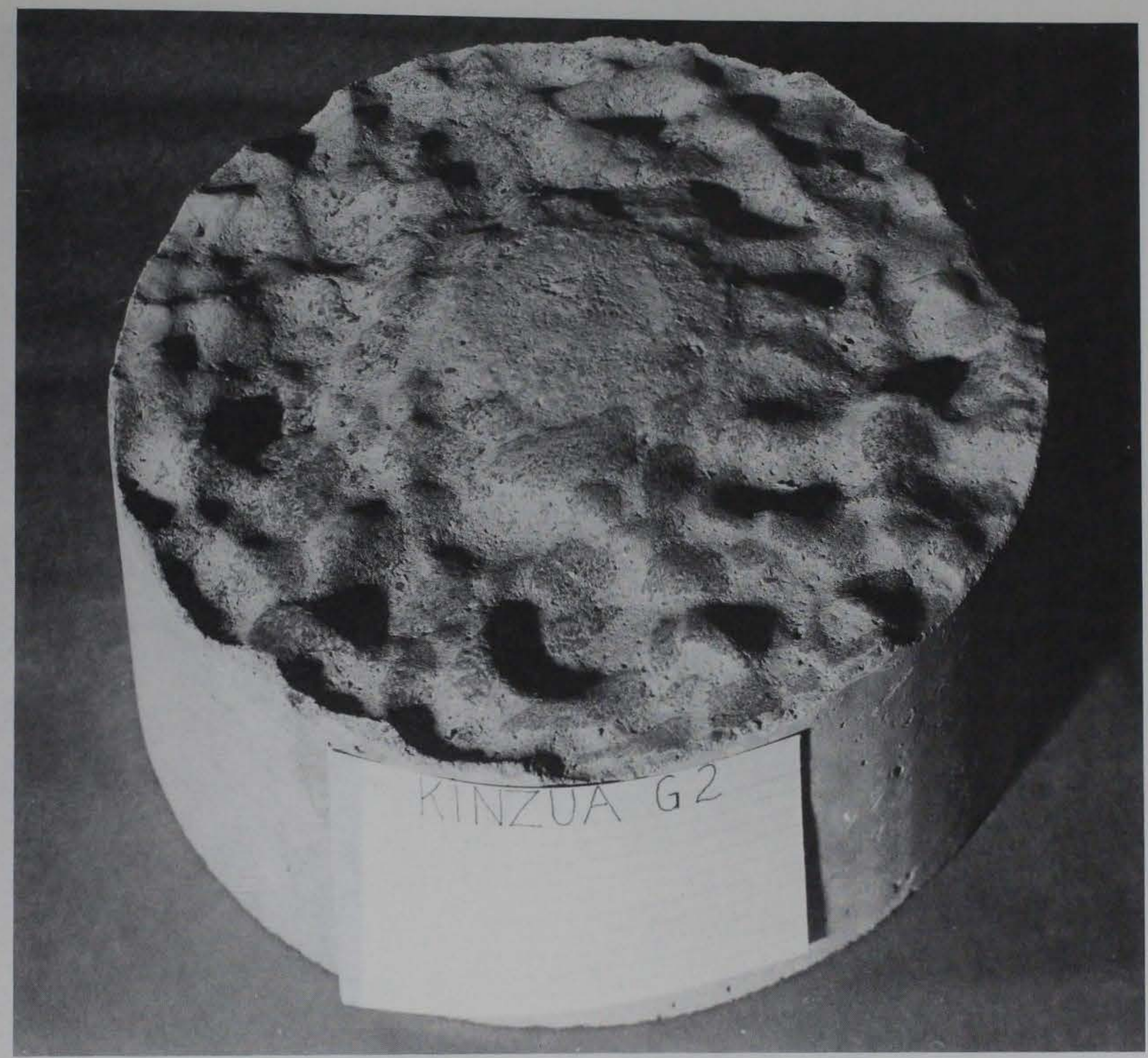

Figure 4. Abrasion-erosion specimen at conclusion of testing, mixture Kinzua G2, 


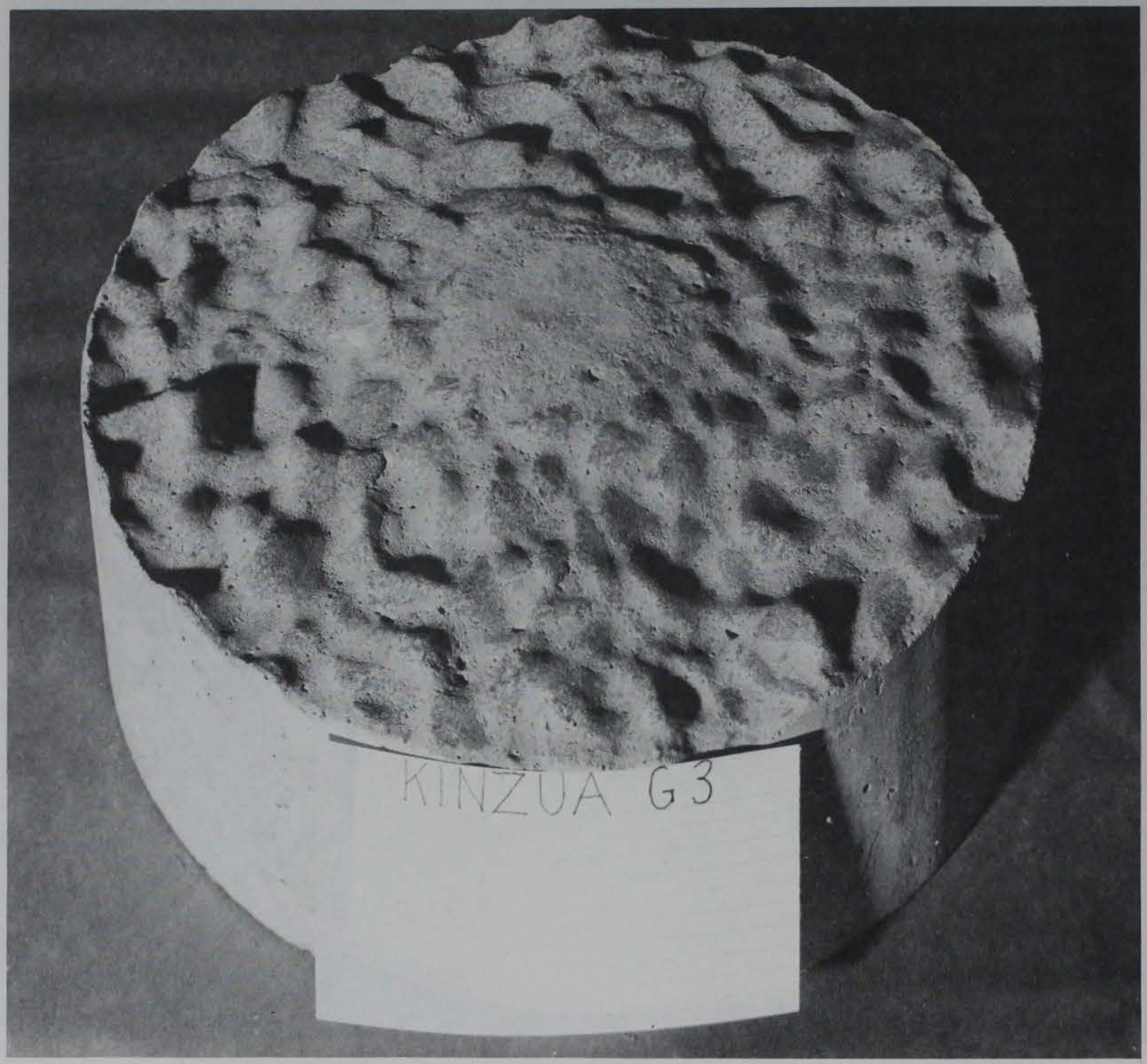

Figure 5. Abrasion-erosion specimen at conclusion of testing, mixture Kinzua G3. 


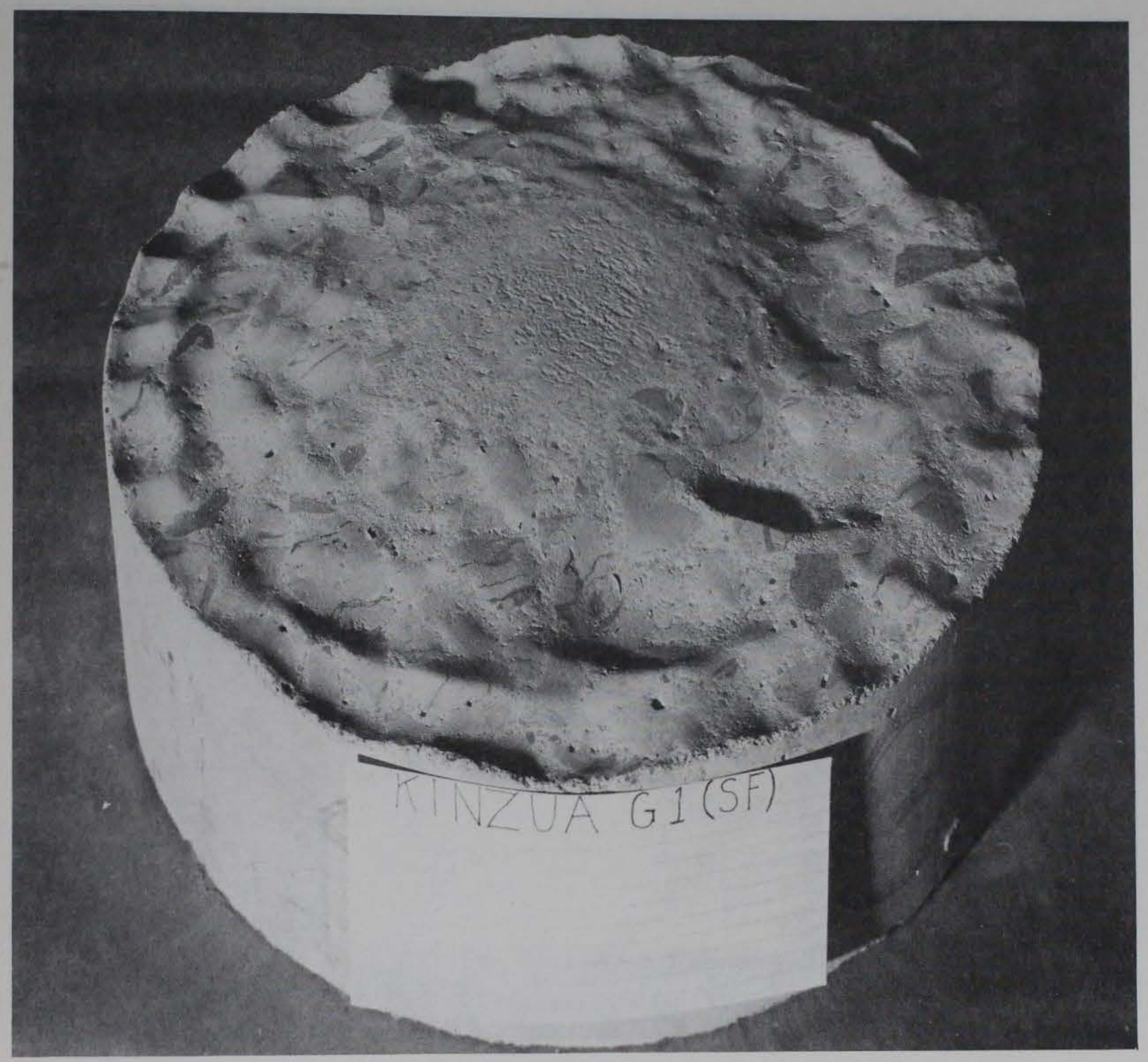

Figure 6. Abrasion-erosion specimen at conclusion of testing, mixture Kinzua Gl(SF). 


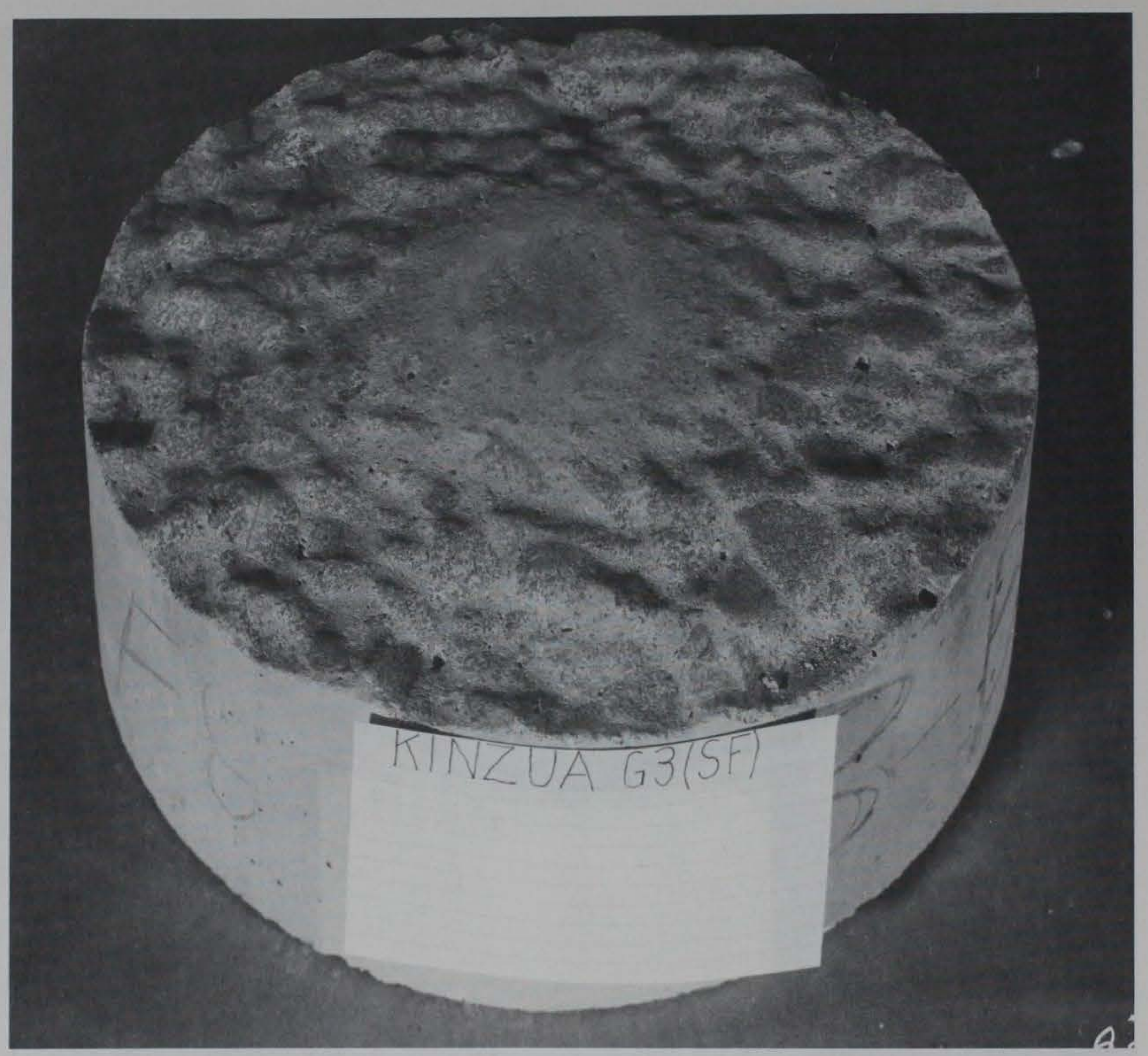

Figure 7. Abrasion-erosion specimen at conclusion of testing, mixture Kinzua G3(SF). 


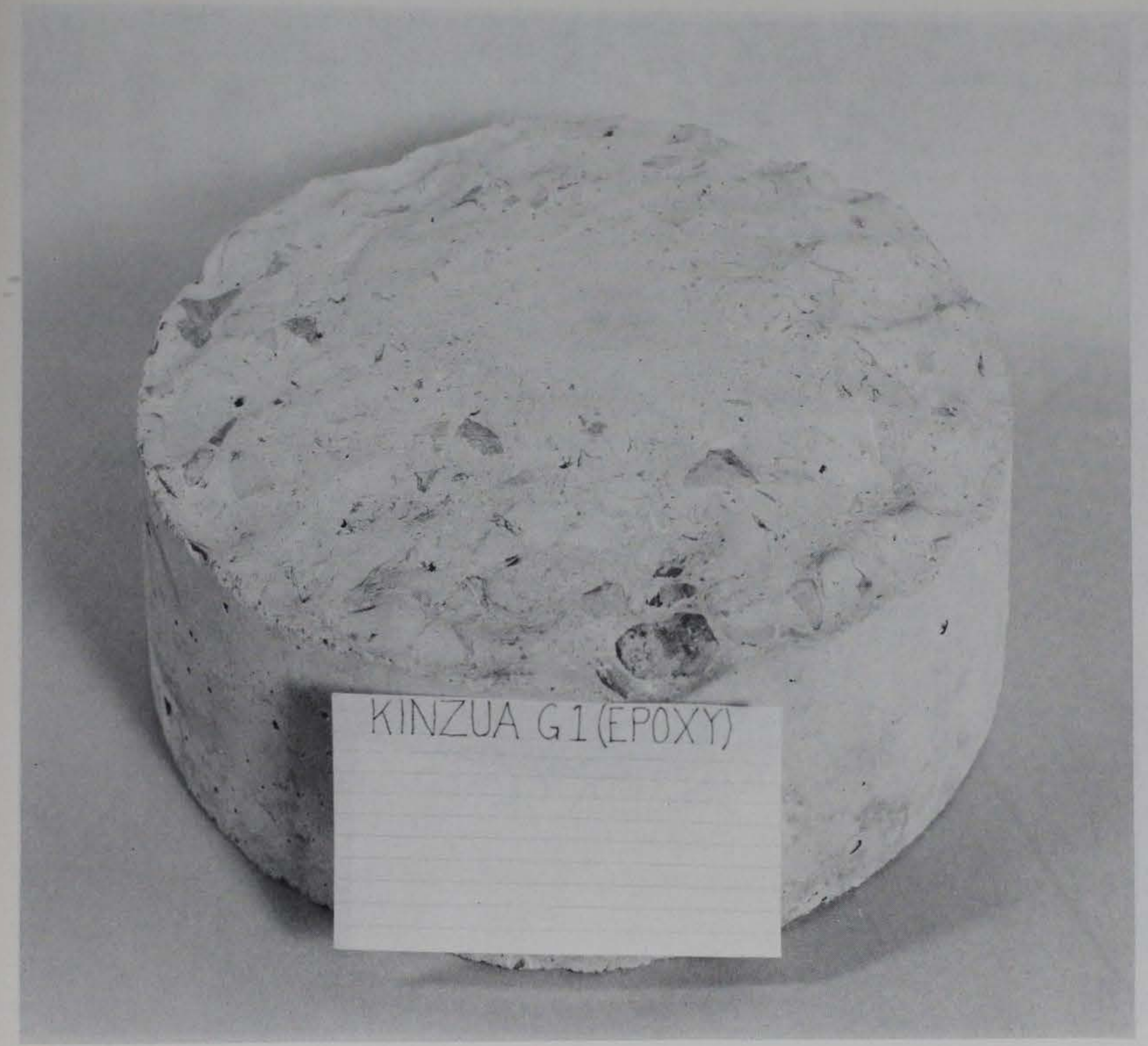

Figure 8. Abrasion-erosion specimen at conclusion of testing, mixture G1 (Epoxy). 


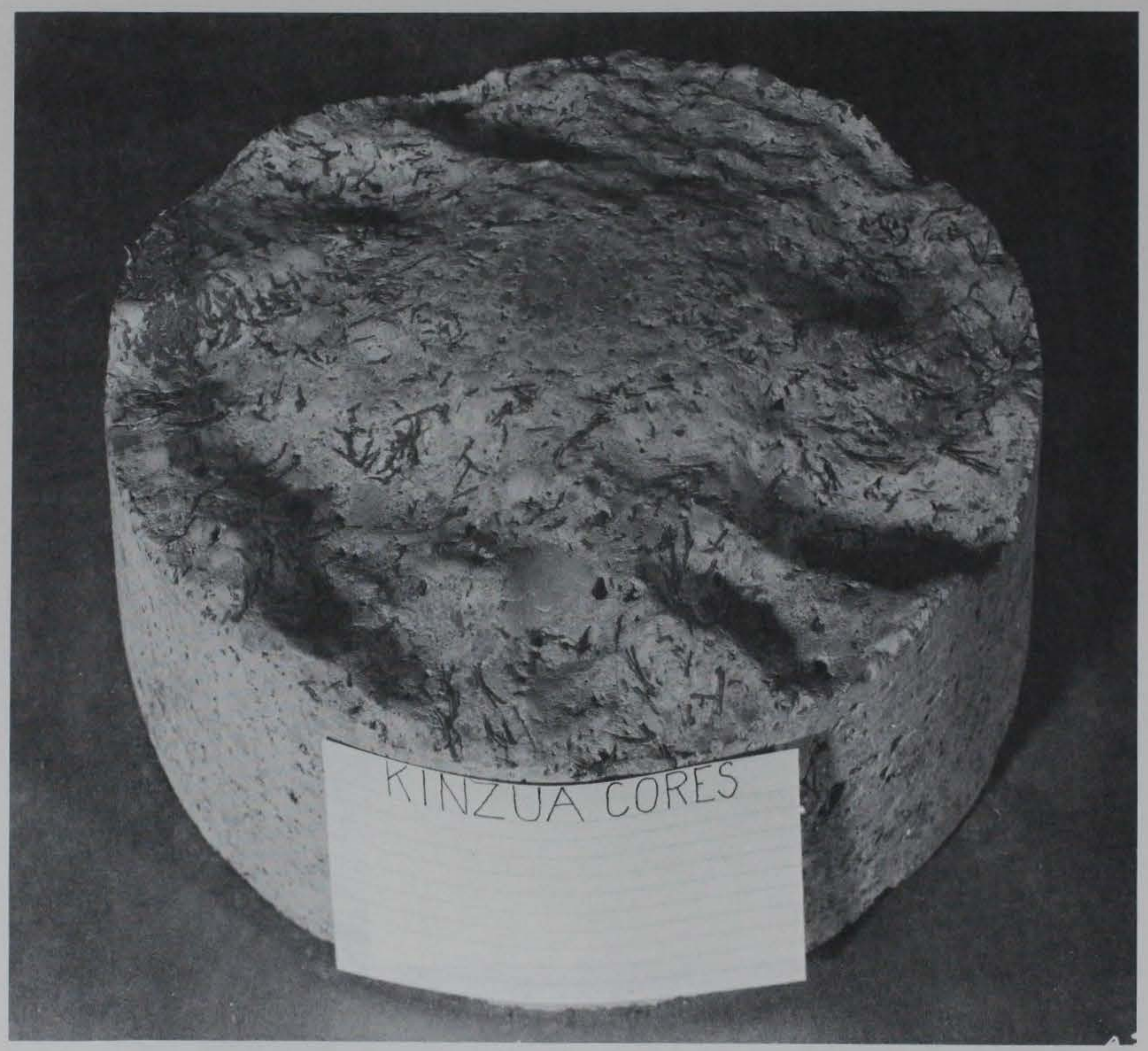

Figure 9. Abrasion-erosion specimen at conclusion of testing, Kinzua cores. 


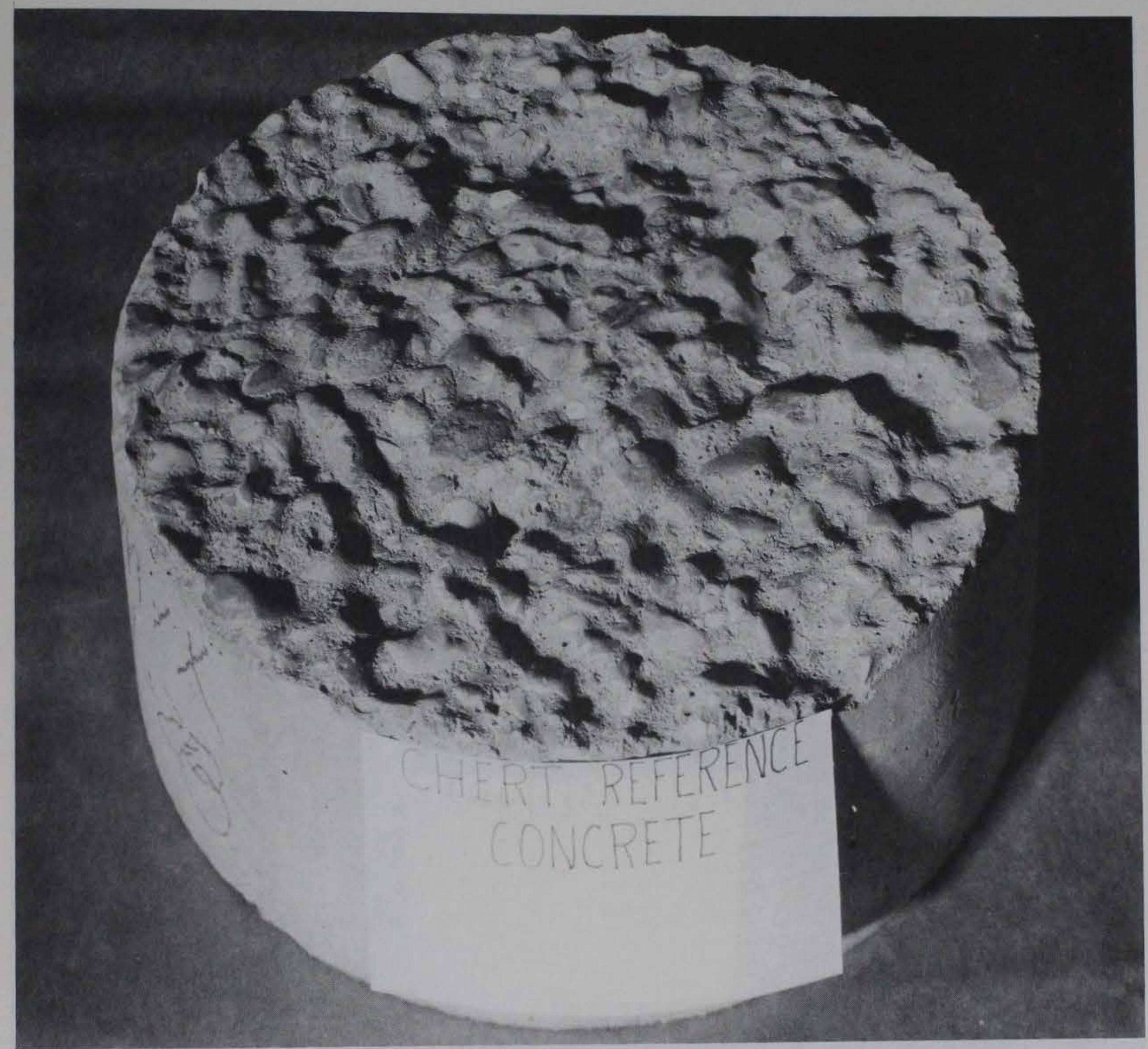

Figure 10. Abrasion-erosion specimen at conclusion of testing, chert reference concrete. 


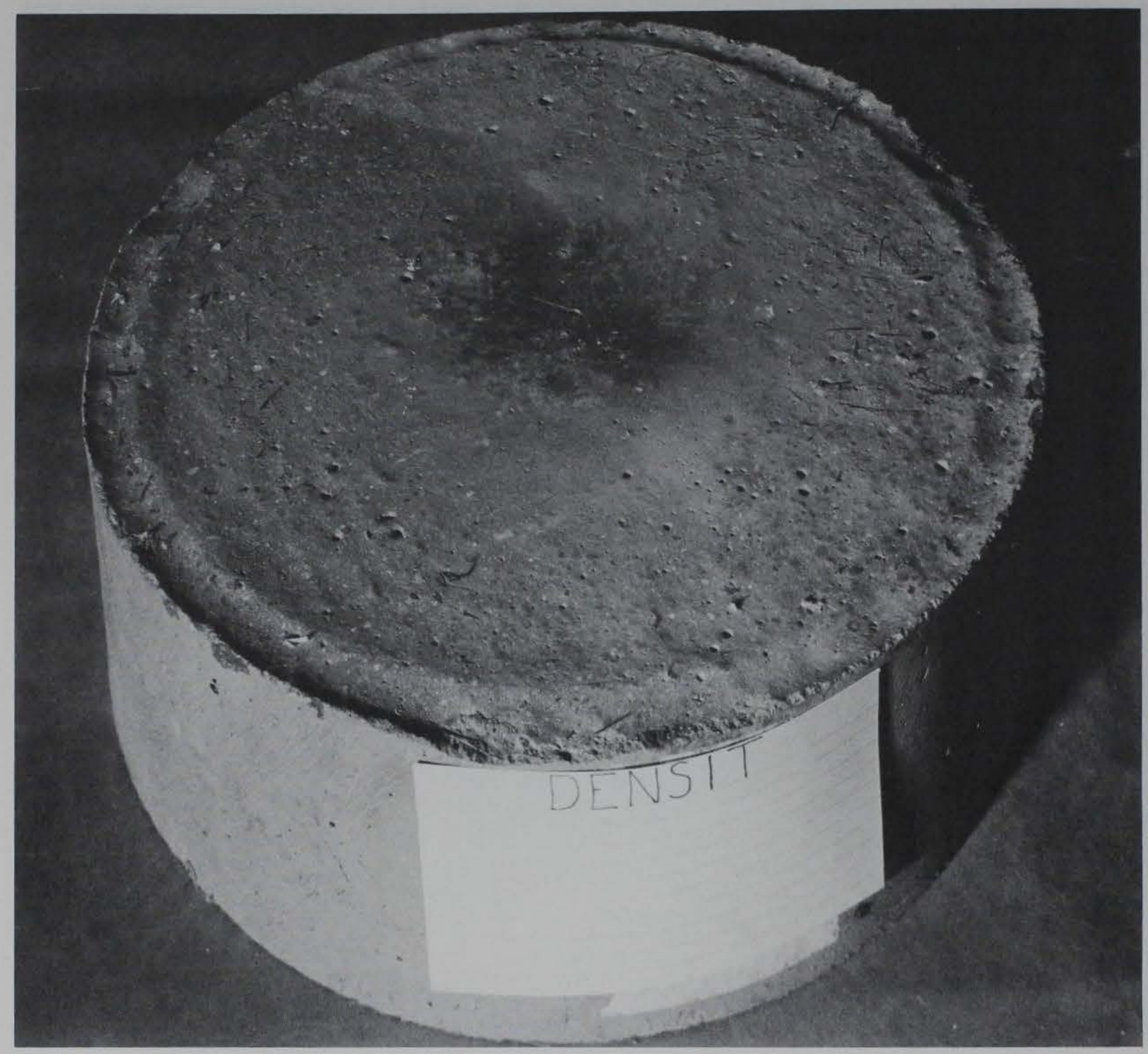

Figure 11. Abrasion-erosion specimen at conclusion of testing, Densit concrete. 


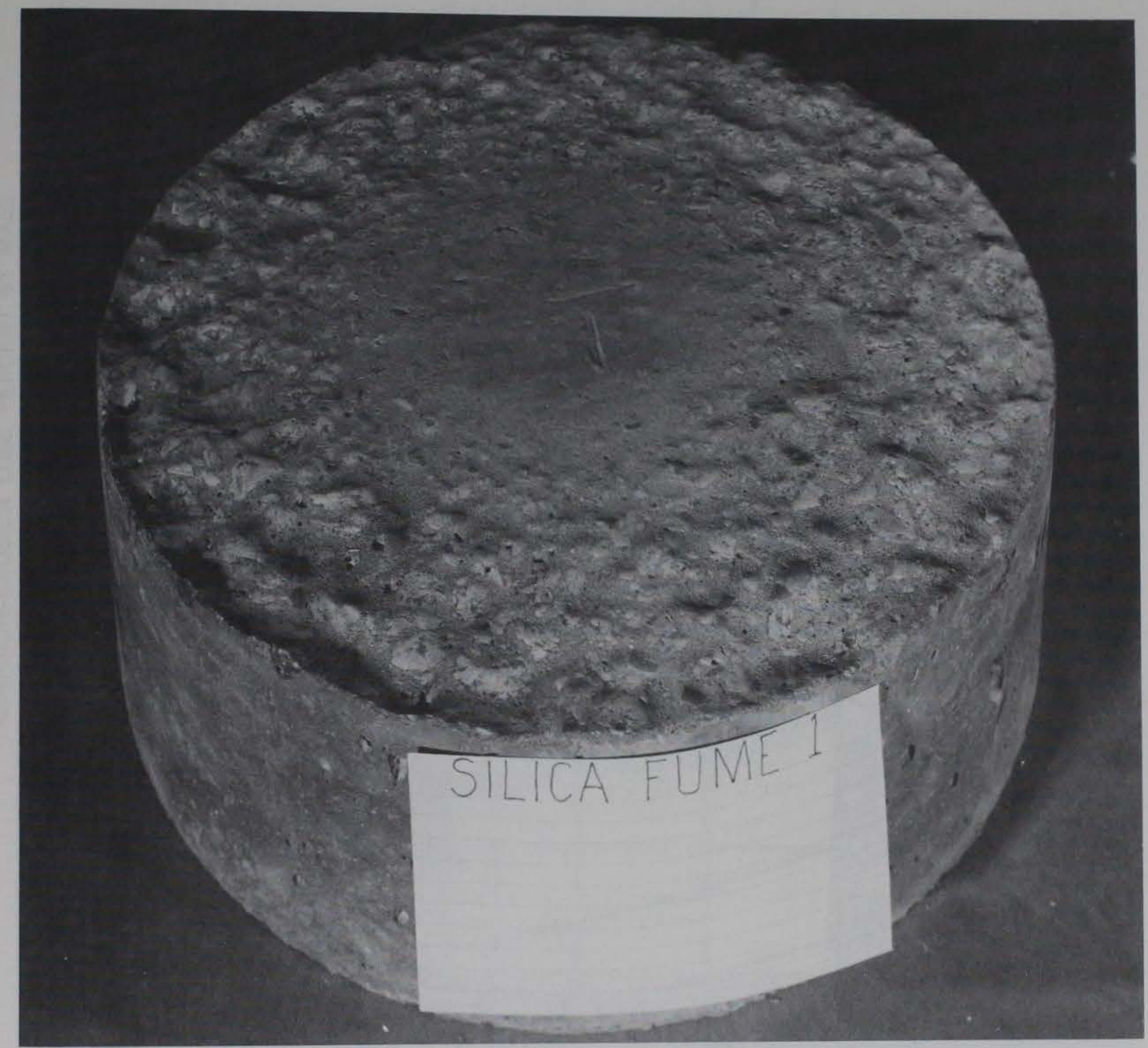

Figure 12. Abrasion-erosion specimen at conclusion of testing, Silica Fume 1. 


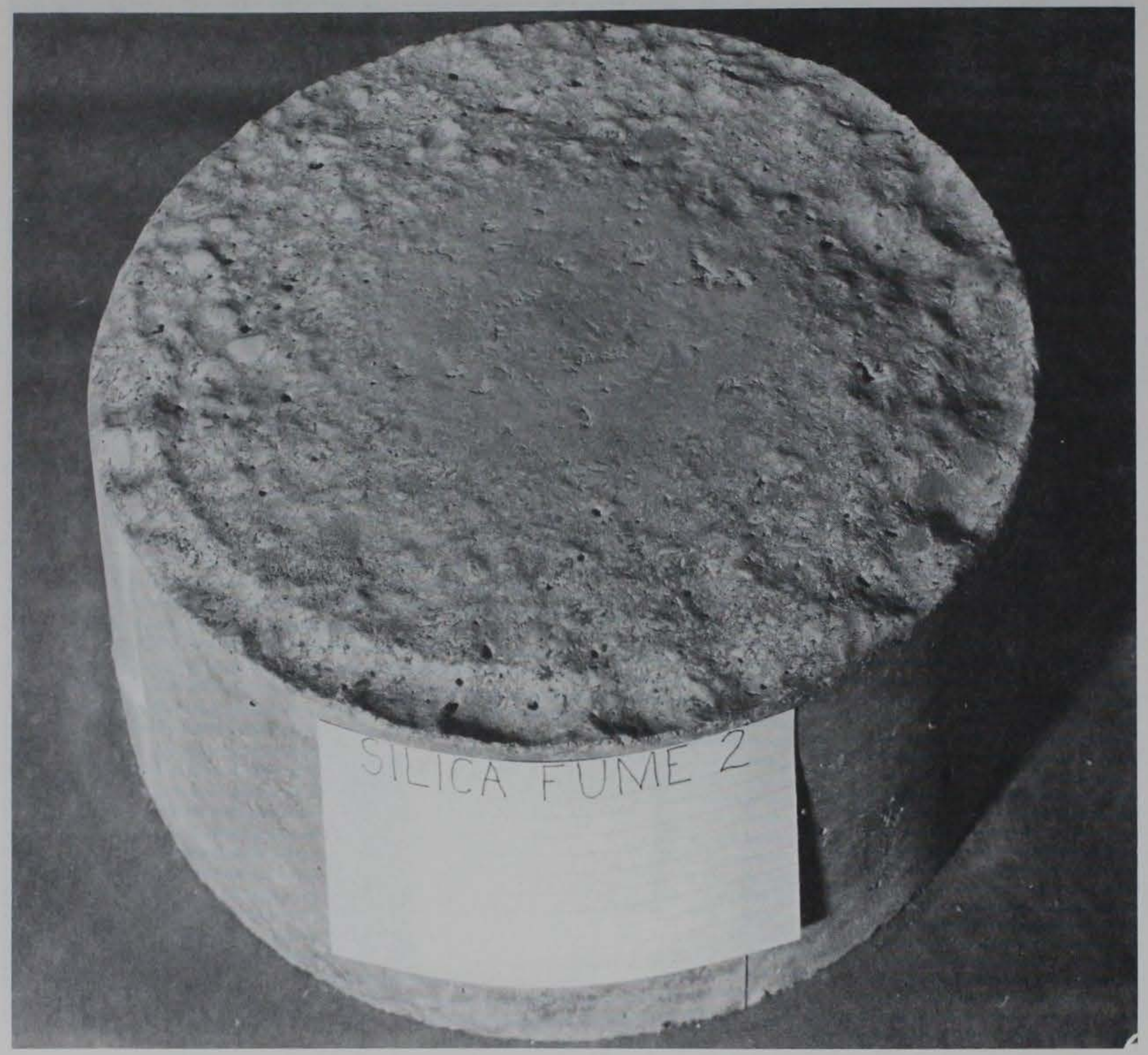

Figure 13. Abrasion-erosion specimen at conclusion of testing, Silica Fume 2. 


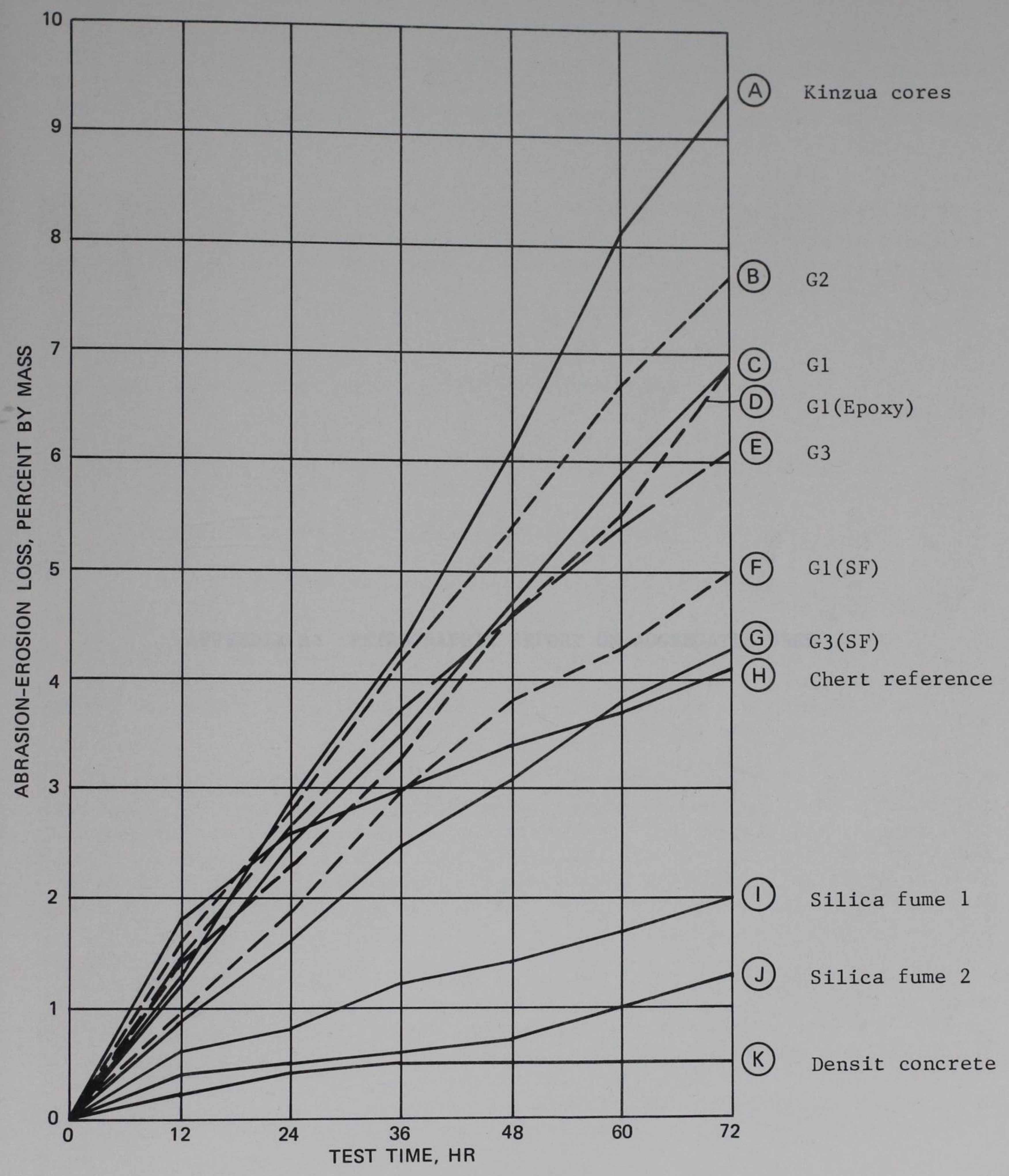

Figure 14. Comparison of abrasion-erosion performance of tested concretes 
APPENDIX A: PETROGRAPHIC REPORT ON AGGREGATES USED 
MEMORANDUM FOR T. C. HOLLAND, CONCRETE TECHNOLOGY DIVISION, STRUCTURES LABORATORY SUBJECT: Limited Petrographic Examination of Four Aggregate Samples

1. These materials are under consideration as concrete aggregates for repair of the stilling basin at Kinzua Dam. Each sample was a small bag of unsized material identified as follows:

\section{a. Coarse aggregate.}

(1) PITT-8 G-1. Limestone from Neidigh Bros. Quarry, Boalsburg, Pennsylvania. New York.

(2) PITT-8 G-2. Diabase from New York Traprock Co., West New York,

(3) PITT-8 G-3. Diabase from Luck Quarry, Leesburg, Virginia.

b. Fine aggregate PITT-8 S-1. Glacial sand from Buffalo Slag Co., Franklinville, New York.

2. Each sample was inspected visually and with a stereomicroscope. A representative portion of each sample was ground to pass a 45- $\mu$ m (No. 325) sieve and examined by X-ray diffraction (XRD). A slurried slide of the sand was treated with glycerol and examined by XRD.

3. PITT-8 G-1. The particles were fine-grained blocky dolomitic limestone with subangular to subrounded edges. Mineral constituents were calcite, dolomite, quartz, and clay-mica. The sample was coated with dust and was medium dark gray (N4).(1) The texture and composition of this rock suggested that it could be potentially reactive when used with high-alkali cement. This can be evaluated by length-change testing of the rock if an adequate sample is available (i.e., larger particles).

4. PITT-8 G-2 and PITT-8 G-3. These two samples of igneous rock were both listed as diabase. A more correct rock name by the classification system of Shand (2) would be gabbro. X-ray diffraction showed each to consist of plagioclase feldspar, pyroxene, amphibole, and some quartz and clays. Color was dark gray (N3). (1) Particle shape was blocky to pyramidal. Sample G-2 was much coarser grained than G-3. Sample G-3 seems to contain more clayey material and may be less durable because of this difference.

(1) The Rock Color Chart Committee, E. N. Goddard, Chairman, "Rock Color Chart,"." 1975, The Geological Society of America, Boulder, Colorado.

(2) Shand, S. J., Eruptive Rocks, 3rd ed., John Wiley and Sons, Inc., New York, New York, 1947. 
SUBJECT: Limited Petrographic Examination of Four Aggregate Samples

5. PITT-8 S-1. This sand was composed of rock and mineral fragments with larger particles ranging from blocky to tabular. Recognizable rock types were limestones and sandstones. XRD showed the presence of quartz, plagioclase and potassium feldspars, calcite, dolomite, and clays. The clays were chlorite and/ or vermiculite, clay-mica, and maybe kaolinite. There was no swelling clay.

JOYCE C. AHLVIN

Concrete Technology Division

Structures Laboratory 
APPENDIX B : EPOXY DATA SHEET 


\section{Sikadur 362 \\ Epoxy modifier \\ for concrete and mortar}

\section{Technical Data}

101 .

Description:
Where to Use:
Sikadur 362 is a pre-proportioned, 2-component, high-solids liquid epoxy-resin system. Components are supplied in kit form.

Developed exclusively by Sika, it is formulated specifically for use in portland-cement concretes and mortars. Sikadur 362 will not affect setting time.

When added to your mix, '362' gives you epoxy-modified concrete and mortar with unique advantages ... Sikadur forms a continuous film that coats your coarse aggregate, bridges the micro cracks in the cement-gel matrix, and produces a structural material of greater durability.
- Developed to help you patch and resurface concrete.

- Especially suitable for bridge decks, parking structures, on-grade slabs, hydroelectric facilities, water-treatment plants.

- Produces high-performance concrete and mortar at costs between conventional concrete and mortar and epoxy concrete and mortar.

\section{Advantages:}

- Added to conventional concrete and mortar, Sikadur 362 will substantially increase strengths over standard mixes 2 ways:

a) reduces water content to minimize shrinkage cracking

b) adds epoxy benefits to improve

- compressive strength

- resilience

- tensile strength

- flexural strength

- Produces high adhesion to existing concrete to create a bond in the composite that cannot be separated at the glue line.

- Reduces absorption.

- Freeze/thaw resistance increased dramatically - no change in dynamic modulus (physical properties) was reported even after 362-modified concrete was subjected to 950 cycles of rapid freeze/ thaw, per ASTM C-666 procedure.

- More economical than all-epoxy mixes, 362-modified mixes are ideal for bridge decks, parking structures, etc.

- Thermally compatible for outdoor patching and surfacing in both shallow and deep replacement patches.

- May be used on grade; 362 does not produce a vapor barrier. 
TECHNICAL NOTES:

Packaging: $\quad$ Sikadur 362 is packaged in 2-gallon kits.
Shelf Life:
1 year.

Storage Conditions: Keep in cool, dry place.

Color:

Straw when mixed.

Pot Life:

Approx 30 to 40 minutes.

Proportion:

Use Sikadur 362 at the rate of $2 \mathrm{gal} / \mathrm{sack}$ of cement, one kit per bag. Dosage may be increased for special applications.

\section{Limitations:}

Sikadur 362 concrete and mortar should be mixed with as low a water content as is consistent with proper placing and consolidation.

Not recommended for use at temperatures below 50F. Keep material between $65 \mathrm{~F}$ and $85 \mathrm{~F}$ during mixing. Do not intermix with organic solvents.

Material not to be used with air-entrained cements or with any airentraining agents.

Do not feather-edge. Minimum thickness is $1 / 2$ in.

$\underline{\text { SIKA }}$
A Comp
$9.69 \mathrm{lb} / \mathrm{ga} 1$
B Comp
$8.521 \mathrm{~b} / \mathrm{ga} 1$

26 Aug 82

List price 2 gal unit

$\$ 53.25 /$ gal

or $\$ 106.50$ per kit

HOW TO USE:

Surface Preparation: Concrete surface must be clean and sound. It must be pre-dampened, but be free of standing water.

Chip surface to remove laitance, grease, oil, curing-compounds, impregnations, waxes, friable concrete, and other bond-inhibiting materials. Surface must be roughened to assure optimum bond of the topping; chip to a $1 / 8$-in. profile. 
Mix 1 sack portland cement, $188 \mathrm{lb}$ sand, 4 to $4.5 \mathrm{gal}$ water in mortar mixer, and hold.

Pre-mix 2-gal unit of Sikadur 362. Add contents of B component to A component container, mix with Sika paddle on low-speed (400- to $600-\mathrm{rpm}$ drill). When blended, add to mortar mix and agitate until epoxy-modified bond coat is uniform. Add up to 3.5 gal additional water as necessary for fluidity.

Scrub into surface using stiff-bristled broom. Apply topping before bond coat loses moisture.

\section{Patching/Topping Mortar}

$\begin{array}{lr}\text { Portland cement } & 1 \text { sack } \\ \text { Concrete sand } & 282 \mathrm{lb} \\ \text { Sikadur } 362 & 2 \mathrm{gal} \\ \text { Water } & 5.5 \mathrm{gal}\end{array}$

Approx yield $\quad 3.2 \mathrm{cu} \mathrm{ft}$

To mix, follow bond coat procedure. Use only that amount of water to give you proper handling and consolidation.

\section{Concrete Mix}

Portland cement

Concrete sand

$3 / 8$-in aggregate

Sikadur 362

Water

1 sack

$296 \mathrm{lb}$

$163 \mathrm{lb}$

2 gal

$5.5 \mathrm{gal}$

\section{Approx yield $\quad 4.2 \mathrm{cu} \mathrm{ft}$}

Mixing procedure: Place coarse aggregate in mixer and add all of Sikadur $362 \mathrm{~A}$ and B components. Mix for approx $3 \mathrm{~min}$. Add sand, some water, then cement. Mix until blend is well dispersed. Add enough or all of remaining water to obtain desired slump. (Water content will vary depending on moisture in sand.)

Note: Mixes are only suggested as guides because local aggregates vary. Your working mix proportions, therefore, should be based on available aggregate.

Application:

Place 362 epoxy-modified concrete or mortar in conventional manner. Finish with a vibrating screed. After screeding, allow bleed water to come to the surface, then finish with steel trowel. Wipe trowel with Sika Equipment Cleaner or other solvent to make it easier. Do not feather-edge Sikadur 362 mixes. Minimum thickness is $1 / 2$ in.

Curing:

Cure with wet burlap and/or polyethylene sheeting for a minimum of $24 \mathrm{hr}$. A 3-day cure is recommended.

Contact SikaService for additional information. 

skin sensitization or other allergic responses. Avoid inhalation of vapor. Use good ventilation particularly if material is heated or sprayed. Prevent all contact with skin or eyes. If contact with skin occurs, wash immediately with soap and water. In case of contact with eyes, flush immediately with water and contact a physician. B Component - DANGER! CAUSES (SEVERE) BURNS. Contains alkaline amines: strong sensitizer. Do not get in eyes, on skin, on clothing. Avoid breathing vapor. Keep container closed. Use with adequate ventilation. Wash thoroughly after handling.

FIRST AID: In case of contact, immediately flush eyes or skin with plenty of water for at least 15 minutes. Remove contaminated clothing and shoes. Call a physician. Wash clothing before reuse. Discard contaminated shoes.

WEAR PROTECTIVE CLOTHING, GOGGLES, GLOVES, AND/OR BARRIER CREAMS.

Keep out of reach of children. For industrial use only.

Every reasonable precaution is taken in the manufacture of all products and compiling of data to assure that they shall comply with Sika's exacting standards. To the best of our knowledge information given is correct and the products as sold are satisfactory for the purpose proposed by Sika. However, no guaranty of results using these products and data is given because every possible variation in methods of use or conditions under which they are applied cannot be anticipated. Sika is not responsible if the material is used in a manner to infringe patent held by others.

Distribution

District Offices

Distributors in principal cities. National network of Sika-approved Applicators.

\begin{tabular}{|c|c|c|}
\hline AL, (Atlanta) ....... 404-761-7143 & LA, Baton Rouge ... 504-927-1859 & NC, (Chester, SC) ... 803-377-3272 \\
\hline CA. Pasadena ...... 213-792-5127 & MA, Boston ....... 617-631-9247 & PA, Philadelphia ... \\
\hline CA. San Francisco .. 415-775-1551 & MD, Rockville ..... & PA, Pittsburgh... \\
\hline CO, Denver......... & MI, Southfield. & $803-377-3272$ \\
\hline CT, Farmington ..... 203-646-0385 & M0, Kansas City... & $214-661-3610$ \\
\hline FL, Lakeland....... & NJ, Cherry Hill .... & $713-461-3010$ \\
\hline GA, Atlanta ...... . 404-761-7143 & NJ, Lyndhurst... . & WA, Redmond. \\
\hline IL, Chicago . . . . . . 312-298-2810 & NY, Middletown . & WI, Milwaukee \\
\hline
\end{tabular}

KS, Shawnee Mission 314-533-1683
WI. Milwaukee ..... 414-272-3100

\section{Executive Office}

\section{Jika sika Corporation}




\section{APPENDIX C: EPOXY MANUFACTURERS CONTACTED}

Following is a list of manufacturers contacted during the attempt to find epoxies suitable for use in fresh concrete. If the company had a suitable product, the product name and approximate cost of epoxy only per cubic yard of concrete are given. Costs are based upon list price information furnished by manufacturers during September 1982.

1. Rocky Mountain Chemical Casper, Wyoming 307-265-3227

Product: Product No. $7, \$ 342$.

2. Sika Corporation Lyndhurst, New Jersey 201-933-8800 Product: Sikadur 362, $\$ 639$.

3. Dural International Corp. Deer Park, New York 516-586-1655

Product: Duralguard, \$454.

4. American Metaseal Co. Carlstadt, New Jersey 201-933-1720

Product: None

5. Protex Industries, Inc. Denver, Colorado 302-935-3566

Product: None

6. Thermal-Chem, Inc.

Elk Grove Village, Illinois 312-364-0364

Product: None

7. General Polymers

Cincinnati, Ohio 513-631-0649

Product: Product data supplied is for an epoxy mortar system.

8. Adhesive Engineering Co. San Carlos, California 415-592-7900

Product: None
9. Delta Plastics Visalia, California 209-732-4823

Product: None

10. Epoxy Industries Ravena, New York 518-745-6193 Product: None

11. Concrete Epoxy Technical Systems, Inc. Trevose, Pennsylvania 215-322-7310

Product: CETS 112, approximately $\$ 350$. 